NBER WORKING PAPER SERIES

\title{
EFFECTS OF PRENATAL CARE ON BIRTH OUTCOMES: RECONCILING A MESSY LITERATURE
}

\author{
Hope Corman \\ Dhaval M. Dave \\ Nancy Reichman \\ Working Paper 24885 \\ http://www.nber.org/papers/w24885 \\ NATIONAL BUREAU OF ECONOMIC RESEARCH \\ 1050 Massachusetts Avenue \\ Cambridge, MA 02138 \\ August 2018
}

This is a draft version of an article that is intended for publication in the Oxford Research Encyclopedia of Economics and Finance. The research was supported in part by the Robert Wood Johnson Foundation through its support of the Child Health Institute of New Jersey at Robert Wood Johnson Medical School, Rutgers University (grants 67038 and 74260). The views expressed herein are those of the authors and do not necessarily reflect the views of the National Bureau of Economic Research.

NBER working papers are circulated for discussion and comment purposes. They have not been peer-reviewed or been subject to the review by the NBER Board of Directors that accompanies official NBER publications.

(C) 2018 by Hope Corman, Dhaval M. Dave, and Nancy Reichman. All rights reserved. Short sections of text, not to exceed two paragraphs, may be quoted without explicit permission provided that full credit, including $\odot$ notice, is given to the source. 
Effects of Prenatal Care on Birth Outcomes: Reconciling a Messy Literature

Hope Corman, Dhaval M. Dave, and Nancy Reichman

NBER Working Paper No. 24885

August 2018

JEL No. I12,I14,I18

\begin{abstract}
Research on the effects of prenatal care on birth outcomes has produced a patchwork of findings that are not easily summarized. Studies have used varying definitions of prenatal care, leading to estimates that are difficult to compare. The identification of causal effects is particularly challenging in this literature because women enter pregnancy with varying states of health, resources and the desire to have a child and it is not feasible to conduct randomized controlled trials that deny care. The content and quality of prenatal care can vary, even across individuals initiating care at the same point in their pregnancies and with similar medical and psychosocial issues. In this chapter, we review the literature on the effects of prenatal care on birth outcomes, highlighting studies with strong research designs and plausible effect sizes. We reconcile the findings to the extent possible, summarize what is known to date, and point to potentially fruitful research directions going forward.

Hope Corman

Department of Economics

Rider University

2083 Lawrenceville Road

Lawrenceville, NJ 08648

and NBER

corman@ rider.edu

Dhaval M. Dave

Bentley University

Department of Economics

175 Forest Street, AAC 195

Waltham, MA 02452-4705

and IZA

and also NBER

ddave@bentley.edu

Nancy Reichman

Rutgers University

Robert Wood Johnson Medical School

Department of Pediatrics

Child Health Institute of New Jersey

89 French St., Room 3272

New Brunswick, NJ 08903

reichmne@rutgers.edu
\end{abstract}




\section{Introduction}

Prenatal care is one of the most frequently used forms of health care in the United States (Schappert 1997; Kogan et al. 1998). This type of care involves a series of encounters during the gestational period, educates women about pregnancy, monitors existing medical conditions, tests for gestational health conditions, and refers expectant mothers to services such as support groups and social services (March of Dimes 2009). Owing largely to expansions of Medicaid for pregnant women in the late 1980 s and early 1990 s, prenatal care has become quasi-universal in the U.S., with over $98 \%$ of mothers giving birth in 2016 receiving at least some prenatal care. However, there is variation in the timing of initiation of that care; e.g., about $23 \%$ of births in that same year occurred to mothers who initiated care after the first trimester of pregnancy, with $4.6 \%$ of mothers initiating during the third trimester of pregnancy. Rates of inadequate care, defined as prenatal care beginning after the fourth month of pregnancy or having fewer than $50 \%$ of the recommended number of visits, are higher among mothers who are young, low-educated, and members of minority groups (Osterman and Martin 2018). Additionally, rates of late and no care are higher among poor and unmarried mothers than among their non-poor and married counterparts (Pagnini and Reichman 2000).

It is the received wisdom that prenatal care improves birth outcomes. In a widely cited 1985 report, the Institute of Medicine estimated that for every dollar spent on more adequate prenatal care for low-income, low-educated women, total expenditures for the medical care of their low birthweight infants during the first year of life would be reduced by $\$ 3.38$; the savings were attributed to a prenatal care-induced reduction in the rate of low birthweight (Institute of Medicine 1988). That report was based on a relatively weak evidence base; subsequent studies, which have generally been more methodologically rigorous, have produced a much cloudier picture.

In this paper, we review and synthesize the economics literature on the effects of prenatal care on birth outcomes. We focus on the economics literature because those studies have generally used 
quasi-experimental econometric techniques in an attempt to identify causal effects. We do not systematically review the broader literature, which would be unwieldy. We do, however, report on relevant studies in the broader literature that were based on randomized controlled trials (RCTs); those studies focused on specific aspects of prenatal care-e.g., home visiting and group prenatal care. We acknowledge that there may be some studies in the broader literature that use quasi-experimental methods at least as strong as some studies in the economics literature. We do not expect that the exclusion of such studies would substantively alter our conclusions.

We focus on studies that built on Michael Grossman's work on the demand for health and health production (Grossman 1972), which spawned the economics literature on prenatal care and birth outcomes beginning with a study by Rosenzweig and Schultz in 1983 (Rosenzweig and Schultz 1983). We used the EconLit database to identify original published research articles from 1983 to date (the writing of this chapter) that estimated effects of prenatal care on birth outcomes in developed countries. All of the studies that turned up in this search focused on the U.S; studies based on the "infant health production" framework in other developed countries have focused on other prenatal inputs, including smoking, that are more policy relevant (than prenatal care) in those contexts. The articles we reviewed in the economics literature are summarized in Table 1. We also conducted a Medline search with the following key words and no date limitations: prenatal care, pregnancy outcome, and "randomized controlled trials as topic." This search yielded several meta-analyses, which we broadly summarize after the more detailed review and synthesis of the economics literature.

In the subsequent sections of this chapter, we provide definitions and context vis-à-vis prenatal care and birth outcomes in the U.S.; present a generalized "infant health production function" model, the theoretical framework used by economists to study the effects of prenatal care on infant health; provide a review of the empirical studies using the infant health production framework to investigate effects of prenatal care on infant health, briefly discuss the body of work using RCTs to evaluate specific 
features of prenatal care, and draw inferences about effect sizes to the extent possible; and conclude with a section on what we have learned from this research and what still needs to be known.

\section{Definitions and context}

In this section, we review how prenatal care and birth outcomes have been measured in research studies and present relevant context vis-à-vis birth outcomes and prenatal care in the US.

\section{Measuring prenatal care and birth outcomes}

Because prenatal care is a heterogeneous good, with educational, medical, and social work components and specific packages of features (beyond basic screeners, tests, and guidance) tailored to individual clients' needs (at least, ideally), characterizing its use for quantitative analysis is not straightforward. As a result, the measures used in population-based research studies tend to be quite crude and capture quantity rather than quality. Most studies focus on the timing of prenatal care initiation (e.g., first trimester versus later care, month of pregnancy in which prenatal care was initiated). Other studies consider the number of visits, either directly or in indices that incorporate timing of initiation and number of visits in an attempt to capture prenatal care adequacy. The number of visits alone can be a problematic indicator of prenatal care use because it conflates preventive care use with medical need. The indices of prenatal care adequacy that have been used in research studies are based on somewhat different standards and assumptions, but all combine information on timing of initiation and number of visits (see Alexander and Kotelchuck 1996 for a critical review of the various indices). As indicated earlier, randomized controlled studies have focused on specific aspects of prenatal care-e.g., group prenatal care, home visits - that are much more easily characterized.

An important consideration with the various measures of prenatal care is what the relevant margin should be. For example, many studies consider whether the mother obtained prenatal care in the first trimester of pregnancy (roughly during the first three months). The alternative is initiating prenatal care any time after first trimester or not at all, and the estimates thus conflate effects for 
women with slightly delayed care with those for women with no care, which would have different implications for the targeting of programmatic interventions. Continuous measures of prenatal care (including days/weeks/months of prenatal care delay or number of visits) yield constant average marginal effects, so that a one month delay, for example, has the same estimated effect on the birth outcome whether the woman goes from a three month to a two month delay or an eight month to a seven month delay, which is not necessarily the case. Another consideration is the reliance on selfreports of prenatal care in most studies, which can bias the estimates.

The most common birth outcomes in research studies of the effectiveness of prenatal care are birthweight (in grams) and low birthweight (less than 2500 grams, or about 5.5 pounds). For birthweight in grams, average effects should be considered in light of the overall distribution of this outcome; e.g., increases in birthweight from 2000 to 2100 grams and from 3400 to 3500 grams may not have same consequences for infant health. Low birthweight is a widely used and much studied marker of infant health; it is a leading risk factor for infant mortality, and infants who survive are at elevated risk for many long-term health conditions and developmental disabilities. Some studies consider very low birthweight (less than 1500 grams, or about 3.3 pounds), an extreme birthweight-related outcome that is associated with particularly adverse health and developmental outcomes. Birthweight is well measured, reliably recorded, and readily available from vital statistics files and many other data sets. Some studies consider gestational age-related outcomes, generally distinguishing between preterm (less than 37 weeks) and term (37 weeks or more) births. Some consider small-for-gestational age (SGA) or growth retardation as an outcome; SGA infants are typically those in less than the 10th percentile in sexspecific birthweight for gestational age. All low birthweight babies are preterm or growth-retarded (they can be both), and virtually all very low birthweight babies are preterm.

Finally, although birthweight measures are accurately reported and low birthweight is correlated with subsequent morbidity and mortality, many infants who are low birthweight end up 
experiencing no subsequent health problems and some infants who are of normal weight at birth experience significant morbidities. In this spirit, some studies used measures of neonatal mortality, abnormal infant health conditions, and newborn hospital costs as outcomes.

Birth outcomes and prenatal care use in the U.S. in context.

Figures 1 and 2 present trends in first trimester and late (third trimester or no) prenatal care, respectively, in the U.S. from 1970 through 2003. Rates of first trimester care increased substantially over the three decades, particularly during the 1990s. In 1970, about two thirds of births were to mothers who initiated care in the first trimester of pregnancy. By 2003, after which changes in the reporting of prenatal care made it impossible to derive a consistent time series, almost $85 \%$ of births were to women who received first trimester care. During the same period, rates of late or no prenatal care declined from about $8 \%$ of births to $3.5 \%$ of births. A major determinant of these trends was a series of dramatic expansions in Medicaid eligibility for poor pregnant women during the late 1980s and 1990s (Currie and Gruber 1996).

Figure 3 shows the percent of infants born low birthweight (weighing less than 2,500 grams) in the U.S. from 1970 through 2015. Rates of low birthweight varied little over the 45 years because numerous (often opposing) forces were at play, including increases in maternal age and education, increases in women's labor force participation, advances in reproductive technology, increases in multiple births, increases in obesity, decreases in cigarette smoking, decreases in fetal mortality, and changing demographics of the U.S. The rate of low birthweight in the U.S. was slightly higher in 2015 than in 1970, but because of all of the concurrent changes, the higher rate should not necessarily be interpreted as a worsening problem. The rate of low birthweight is higher in the U.S. than in most other developed countries-e.g., 8.1\% in the U.S. compared to 6.7\% among European Union countries in 2015 (OECD Family Database 2018), although there are some reporting inconsistencies across countries that can distort such comparisons. 


\section{Economic framework}

The economic framework upon which the reviewed studies are based is derived from the seminal work of Grossman (1972) on the demand for health and health production and focuses specifically on the production of infant health. A simplified version of this model can be expressed as a three-equation system, wherein parents' utility can be expressed as a function of consumption goods (C), infant health $\left(\mathrm{H}_{\mathrm{i}}\right)$, parents' health $\left(\mathrm{H}_{\mathrm{p}}\right)$, tastes, and any other relevant arguments as follows: ${ }^{1}$

(1) $\quad U=U\left(C, H_{i}, H_{p}\right.$, tastes $)$

Infant health is a function of prenatal inputs (which can be favorable, such as prenatal care, or adverse, such as smoking or drug use) as well as the health endowment of the mother (which reflects $\mathrm{H}_{\mathrm{p}}$ and may affect her reproductive efficiency), as shown in the infant health production function that follows:

$$
H_{i}=f\left(\text { input }_{1}, \text { input }_{2}, \ldots . . \text { input }_{n}, \text { maternal health endowment }\right)
$$

The demand for each input can be expressed as follows:

(3) $\quad$ Input $_{i}=g_{i}$ (price and availability of input ${ }_{i}$, prices and availability of substitute and complementary inputs, income, maternal health endowment, tastes, wantedness)

Infant health is an argument in the parent's utility function (Equation 1), and the parents' utility maximization is constrained by the process underlying the production of infant health (Equation 2). Wantedness reflects the relative importance of infant health versus other factors (e.g., the mother's own health) in the parent's utility function and therefore impacts prenatal input use (Equation 3) and other investments in infant health that may be unobserved. Maternal health endowment enters the infant health production directly (through biological processes) and may also affect infant health indirectly through the use of prenatal inputs (e.g., mothers with poor health endowments may attempt to offset an expected unfavorable birth outcome by utilizing more healthy inputs). Maternal risk-taking and time preference (taste for risky behaviors) affect maternal engagement in risky prenatal behaviors

\footnotetext{
${ }^{1}$ The model description is borrowed from Reichman et al. (2009).
} 
(such as smoking and drug use) and investments in own health, which in turn can impact infant health production directly through the maternal health endowment (Equation 2) or indirectly through the maternal health endowment or other inputs (Equation 3).

In the review and synthesis that follows, we focus on studies that specifically investigate the role of prenatal care in producing infant health using the above framework (specifically, Equation 2$){ }^{2}$ In our review, we highlight studies that took the literature in new directions by applying different methods, considering new outcomes or measures of prenatal care, or considering heterogeneous effects according to sociodemographic or health-related characteristics. A key methodological challenge in this literature (and many others), often referred to as "endogeneity," is that direct estimation of Equation 2 may produce biased estimates because the demand for prenatal care and other inputs may be correlated with unobserved inputs or maternal characteristics that are associated with the infant health outcome. As we discuss below, methods for addressing this issue have evolved over time in the economics literature on infant health production. Because randomized controlled trials are considered the gold standard in this regard, we also discuss the relatively limited literature outside of economics that has investigated the effects of prenatal care on birth outcomes using RCTs.

\section{Broad overview of literature}

Table 1 summarizes the 25 studies from the economics literature to date that explicitly focused on identifying effects of prenatal care on birth outcomes or allowed for inferences to be made in that regard. For each article, we indicate the measures of prenatal care and birth outcome(s) used, the data source and type of data (e.g., aggregate, individual-level), the broad methodology, and the findings, which include estimated effects of prenatal care, as well as those of prenatal cigarette smoking when

\footnotetext{
${ }^{2}$ We also include two studies that estimated reduced form models that substituted specific determinants of Equation 3 (i.e., indicators of availability of prenatal care) into Equation 2 in lieu of a measure of prenatal care use, and separately estimated a version of Equation 3 that included these same indicators, allowing for inferences about the effects of prenatal care on birth outcomes (Currie and Gruber 1996; Gray 2001).
} 
considered in the same study, on birth outcomes. The smoking results provide useful context, as prenatal smoking is the leading known preventable risk factor for poor birth outcomes (Cnattingius 2004; WHO 2013) and has been studied frequently in the economics literature, with fairly consistent estimates across studies. The most consistent metric for prenatal smoking is birthweight in grams associated with any smoking during pregnancy, and the estimates have been in the "few hundred grams" range (reductions in birthweight attributed to smoking) across four decades of research with evolving methodological sophistication (Corman, Dave and Reichman forthcoming), including a clinical trial of a smoking cessation program directed at pregnant women (Hamilton 2001).

The literature summarized in Table 1 has evolved in a number of ways. First, studies have attempted to address the potential endogeneity of prenatal care in increasingly sophisticated ways, most recently by exploiting relevant policy changes or events as exogenous sources of changes in prenatal care. Second, studies have considered a widening set of prenatal care and birth outcome measures. Third, studies have used a growing number of data sources. Fourth, studies have increasingly considered heterogeneous effects, with some of the early studies stratifying by race and more recent studies modeling differential effects of prenatal care across the maternal or infant health distribution.

The first paper to apply the infant health production framework to investigate the effects of prenatal care on birth outcomes was Rosenzweig and Schultz (1983). In addition to being the first study to investigate the role of prenatal care in an infant health production framework, this paper was also one of the first in the health production literature more broadly (which was not limited to mothers and their infants) to acknowledge and attempt to address the potential endogeneity of health inputs. Using data from the National Natality Followback Survey (1967-69), the authors identified four potentially endogenous inputs - prenatal care delay, smoking, parity, and maternal age-and implemented twostage models that first estimated all four inputs using a set of individual-level and state-or local arealevel instrumental variables, including availability of hospital beds, family planning services, physicians, 
and obstetricians/gynecologists; health expenditures; milk and cigarette prices; and economic characteristics. They then estimated models of birth outcomes (birthweight and birthweight for gestational age) using the predicted values of the endogenous inputs. Under the identifying assumption that these factors impact birthweight only through their effects on the endogenous inputs, and are therefore uncorrelated with the error term in the structural infant health production function (empirical specification of Equation 2), the two-stage estimation would identify a consistent causal impact of the inputs on infant health. Certain specifications of the authors' two-stage models (which we henceforth refer to more generally as instrumental variables (IV) models, given the use of identifying variables for exclusion restrictions) suggest a roughly 50 gram reduction in birthweight, on average, for each month of care delay; these estimates were much larger than the corresponding Ordinary Least Squares (OLS) estimates, which the authors suggested reflects adverse selection into early prenatal care (i.e., unobserved factors were associated with both worse birth outcomes and early care). In other specifications, the authors found smaller or statistically insignificant estimated effects of prenatal care. ${ }^{3}$ Corman, Joyce and Grossman (1987) contributed to this young literature by focusing on neonatal mortality-an extreme marker of poor infant health-as an outcome and modeling racespecific effects. Unlike the Rosenzweig and Schultz study, which used individual-level data, the authors used county-level data, which is useful for studying rare events such as neonatal mortality. They considered prenatal care, abortion availability, and neonatal intensive care use as endogenous inputs in IV models, and also considered potential pathways by estimating the effects of prenatal care, which they characterized as percent receiving first trimester (versus late or no) care, with and without controlling for low birthweight. They identified all of the endogenous inputs with area-level measures of female poverty and education; availability of neonatal care services, family planning services, and

\footnotetext{
${ }^{3}$ Rosenzweig and Schultz (1988) replicated these results with data from a later cohort, and found a somewhat larger effect size of 91 grams in a linear two-stage specification with similar identifiers.
} 
community health centers; and Medicaid availability and generosity. Their IV estimates suggest that a 1 percentage point increase in women who received first trimester prenatal care reduced neonatal mortality by $1 \%$ for both blacks and whites. The IV estimates were twice those of the corresponding OLS estimates for whites and four times the corresponding OLS estimates for blacks, again suggesting adverse selection into early prenatal care.

Grossman and Joyce (1990) addressed the issue of self-selection of pregnant women into live births (versus terminating their pregnancies), which could potentially bias the estimated effects of prenatal care on birth outcomes, even in IV models. Using individual-level birth data from New York City, the authors included other health-related inputs into their models (i.e. tobacco, alcohol and narcotic use), but modeled only prenatal care as an endogenous input in IV models, using availability of abortion providers and family planning clinics, poverty rates, individual-level Medicaid use, and individual-level spontaneous and induced abortions to identify the sample selection model, and using prenatal care clinic and WIC clinic availability, poverty rates in the health area districts, individual-level parity, and health insurance status plus the sample selection parameter (inverse of the Mills ratio, lambda, from the selection model) as identifiers for prenatal care use. This was the first study to focus on one specific endogenous input in the infant health production function and rigorously model the effect of that one input. They found that each month of prenatal care delay led to decreases in birthweight that were quite modest (4 to 37 grams, depending on specification and race) and that these IV estimates were 3-6 times larger than the corresponding OLS estimates.

The empirical issues and difficulties in identifying the causal effects of prenatal care (and other maternal inputs) on infant health were well-recognized from the start, as evidenced by these early studies' attempts to address potential bias from unobserved heterogeneity and selection. Andrew Jones (1991) encapsulated some of these and other econometric concerns, including collinearity of multiple inputs, appropriate functional form, omitted variables and other sources of endogeneity, heterogeneous 
effects, and the importance of specifying a behavioral model to distinguish exogenous vs. choice variables, within a study of low birthweight using aggregate state-level data. He found some beneficial effects of early (first trimester) prenatal care on the prevalence of low birthweight, though the effect was marginally significant only for whites and relatively small in magnitude (a 10 percentage point increase in births among women receiving early prenatal care was associated with a 0.18 percentage point reduction in the prevalence of low birthweight infants).

Frank et al. (1992) used aggregate county-level data to estimate fixed-effects models of effects of first trimester care on race-specific rates of low birthweight. State and year fixed effects allowed the authors to control for variations in potentially confounding factors that varied by state and year. Their models included measures of first trimester care, smoking, abortion, first birth, and income as inputs in the production function. The findings from this study suggest that a 1 percentage point increase in first trimester care led to reductions in low birthweight of 0.007 percentage points for white women and 0.018 percentage points for black women.

Joyce (1994) introduced a new measure of prenatal care into this literature-levels of adequate, intermediate, or inadequate care, based on the modified Kessner index. Focusing on birthweight as the outcome, Joyce used individual-level data on births in New York City to estimate IV models with health insurance type, poverty rates, and availability of prenatal care clinics, family planning clinics, WIC centers, and abortion providers as identifiers for adequacy of prenatal care. As in Grossman and Joyce, this study also focused exclusively on prenatal care as the endogenous input in the infant health production function. In his preferred model specification (IV models that treated prenatal care, but no other inputs, as endogenous), he found that adequate (vs. inadequate) care led to increases in birthweight of 170 grams for blacks, 287 grams for whites, and 249 grams for Hispanics. These effect sizes were about 3 times higher than the corresponding OLS estimates for blacks and Hispanics and about $43 \%$ higher for whites, suggesting adverse selection into adequate prenatal care. The direction of 
the selection bias was consistent with the patterns found by Rosenzweig and Schultz and by Grossman and Joyce.

Currie and Gruber (1996), Gray (2001), and Sonchak (2015) further focused on prenatal care as an input using variations in Medicaid policies, which are arguably more exogenous and directly relevant sources of identification than many of the identifiers used in previous studies. Currie and Gruber estimated the effects of Medicaid eligibility expansions for pregnant women on state-level rates of low birthweight and infant mortality using IV models with measures of Medicaid eligibility rules as identifiers for Medicaid eligibility. Using a separate data set, they found that the Medicaid expansions increased the use of first trimester prenatal care by up to $47 \%$, allowing for inferences to be drawn about the effects of prenatal care on birth outcomes in the presence of a strong treatment. The authors found that the increase of eligible women due to the Medicaid expansions (an increase of about 30 percentage points) led to a $1.9 \%$ reduction in low birthweight and an $8.5 \%$ reduction in infant mortality. However, most of the reduction in infant mortality appeared to be due to postnatal interventions rather than prenatal care. Thus, the Medicaid expansions, which led to large increases in prenatal care use, had relatively modest effects on low birthweight.

Gray (2001) and, much later, Sonchak (2015) investigated the effects of Medicaid reimbursement rates on birth outcomes, allowing inferences to be drawn about effects of prenatal care on birth outcomes. Gray used individual-level data from the 1988 National Maternal and Infant Health Survey to estimate difference-in-differences models that controlled for unobserved state-level characteristics that may have been associated with both Medicaid reimbursement rates (which could affect not only quantity but also quality of care) and birth outcomes. The author found that a $10 \%$ increase in relative Medicaid fees led to about a one percentage point (2.1\%) increase in use of first trimester prenatal care, a 0.1 percentage point decrease (4.5\%) in very low birthweight, a 0.4 percentage point decrease (3.8\%) in low birthweight, and no significant changes in preterm birth or 
infant death among women on Medicaid. By inference, a one percentage point increase in first trimester care led to the 0.1 and 0.4 percentage point decreases in very low birthweight and low birthweight, respectively.

Based on Gray's finding that Medicaid reimbursement rates increased the use of prenatal care using a single year of data, Sonchak expanded the sample and investigated the effects of reimbursement rates on a range of measures of prenatal care utilization (number of visits, first trimester care, no prenatal care, and the Kessner index of prenatal care adequacy) and a range of birth outcomes (birthweight, low birthweight, gestational age, and preterm birth) using individual level data from 20012010 U.S. birth records within an IV framework. Using state reimbursement rates as identifiers for prenatal care visits, Sonchak found that additional prenatal visits increased birthweight for white women with less than a high school education (including teens), but not for black women with less than a high school education (including teens); for the former, one additional prenatal visit increased birthweight by between 21 and 25 grams but had no significant effects on low birthweight, gestational age, or preterm birth. In the first-stage equation, she found that a $10 \%$ increase in reimbursement rates increased prenatal visits by 0.11 for low-educated black mothers and about 0.07 for low-educated white mothers (about $1 \%$ relative to the respective means). Among high school dropouts, there was some evidence that higher reimbursement rates significantly decreased the likelihood of no prenatal care for white mothers (but not black mothers), but there were no associations between reimbursement rates and first trimester care or the Kessner index. For less disadvantaged samples, there were statistically significant positive associations between reimbursement rates and the Kessner index for white and black mothers with a high school education and for black mothers with a college education, as well as a negative association between reimbursement rates and no prenatal care for black mothers with some college education. 
Reichman and Florio (1996) and Joyce (1999) investigated the effects of enhanced prenatal care programs for women on Medicaid that provided more intensive (higher quality) services compared to standard Medicaid prenatal care. Reichman and Florio focused on New Jersey's HealthStart program, which included an increased number of prenatal visits, increased provider reimbursement, case coordination, integrated health support services, case managers, and community outreach. They used linked birth/death and hospital discharge records for Medicaid births in New Jersey in 1989 and 1990 and estimated OLS and IV models that used numbers of HealthStart providers in the woman's residence city at least six months before she gave birth as identifiers for HealthStart participation.

Econometric tests suggested that the OLS estimates were not biased. In their OLS models, the authors found that enriched prenatal care (compared to standard Medicaid prenatal care) increased birthweight by 55.7 grams, decreased low birthweight by 3.7 percentage points, decreased very low birthweight by .9 percentage points, and decreased newborn hospitalization costs by $6.9 \%$ for black women, but had no effects on any of these outcomes for white women. Of the 55.7 gram improvement in birthweight, 5-15 grams could be explained by prenatal care delay and the rest was attributed to the program itself, which could have involved the increased number of prenatal care visits or its other features. In addition, because the program made other services (such as the Special Supplemental Nutrition Program for Women, Infants, and Children) more available than they would be through standard Medicaid prenatal care (through intensive case management) , the favorable effects of prenatal care found in this study could potentially reflect effects of services other than prenatal medical care.

Joyce studied the effects of the New York State Prenatal Care Assistance Program (PCAP), which was similar to New Jersey HealthStart program, using linked Medicaid and birth records from New York City for 1989-1991. He estimated both OLS and IV models, with the latter using proxies for the growth in PCAP providers as a result of the state's expansion in Medicaid eligibility (in January 1990) as identifiers 
for PCAP participation. In OLS models, PCAP (compared to standard Medicaid prenatal care) was found to increase birthweight by 33-83 grams (depending on year and subsample), decrease low birthweight by 1.5-3.7 percentage points, and decrease very low birthweight by 0.4 to 1.3 percentage points. The IV estimates were insignificant and not robust, suggesting that the expansion in PCAP participation had relatively little impact on birth outcomes. Notably, while Reichman and Florio found significant effects only for black women in their study of enhanced care under New Jersey's HealthStart program, Joyce did not estimate race-specific models in his study of the PCAP program in New York City.

Abrevaya (2001), Conway and Deb (2005), and Abrevaya and Dahl (2008) looked beyond average treatment effects and considered heterogeneity in the effects of prenatal care on birth outcomes by the health of the mother during pregnancy (Conway and Deb) and along the birthweight distribution (Abrevaya 2001, Abrevaya and Dahl 2008). Using U.S. birth records from 1992 and 1996 and estimating quantile regressions, Abrevaya found that the impact of prenatal care varied substantially across the distribution of birthweight, and that the average effect estimated by OLS masked this considerable heterogeneity. Specifically, he found that no prenatal care (compared to first trimester care) reduced birthweight by 389 grams for those in lowest decile of the birthweight distribution, with monotonically declining effects at higher points in the distribution ranging in effect sizes from 100 to 200 grams; in comparison, the OLS estimate indicated a 194 gram reduction in birthweight. Other trimesters of care (compared to first) had small and inconsistently-signed effects on birthweight. While Abrevaya did not account for the endogeneity of prenatal care, the results from this study underscore that prenatal care may have very different effects depending on the course of the pregnancy and that the most beneficial effects may be concentrated among births most at risk for adverse birth outcomes.

Conway and Deb used data from the 1988 National Maternal and Infant Health Survey and estimated finite mixture models to assess heterogeneity in the causal effect of prenatal care on birthweight. Unlike Abrevaya, the authors addressed the endogeneity of prenatal care (measured as 
weeks of care delay), drawing on earlier studies and using cohabitation status, income, insurance status, state-level healthcare price index, and population density as identifiers. They drew attention to the potential misspecification that arises under the standard assumption (implicit in much of the prior work) that all births are drawn from the same distribution. Departing from this approach, Conway and Deb employed a two-class finite mixture model, wherein the observed birthweight distribution was assumed to be a "mixture" of two latent classes, or separate distributions, consisting of "normal" and "complicated" pregnancies. While the latent factors determining the two distributions were unobserved, the classes were characterized ex post using observed characteristics. The latent class of "normal" pregnancies included about $86-87 \%$ of all births and had a mean birthweight of 3158 and 3360 grams (for black and white mothers, respectively), while the latent class of "complicated" pregnancies included about $13-14 \%$ of all births and had a mean birthweight in the very low birthweight range (1200 grams for white mothers and 1079 grams for black mothers). The authors found that one week of prenatal care delay led to a 30-35 gram reduction in birthweight for "normal" pregnancies (this finding was robust across model specifications) and no effects of prenatal care on "complicated" pregnancies. These findings underscore the importance of considering medical risk of mothers when assessing the effects of prenatal care. That is, prenatal care may appear to be ineffective when a sample includes complicated pregnancies that may be relatively unaffected by prenatal care. However, these findings are not necessarily compatible with those of Abrevaya, who found larger effects for infants with lower birthweights (which could reflect mothers' higher medical risk). This apparent disparity in findings may reflect the treatment of the endogeneity of prenatal care or the different approaches to modeling the heterogeneity. While quantile regression methods identify heterogeneity specifically across the outcome (in this case, birthweight) distribution, finite mixture models do not fully capture this source of 
heterogeneity (e.g., while the latent class denoted "normal pregnancies" had a mean birthweight of 3200-3400 grams, this class could have included some births that are low birthweight).

Abrevaya and Dahl (2008) expanded this line of inquiry even further by not only allowing the effect of prenatal care to vary depending on the point in the birthweight distribution, but also by considering differential effects by trimester of care. Using birth records from Washington State and Arizona between 1992 and 2002 and estimating quantile regressions, they found that no prenatal care reduced birthweight by 323 grams at the 10 th percentile of birthweight, had no significant effects at the 25th to 90th percentiles, and increased birthweight by 271 grams at the 90th percentile of birthweight. Extending Abrevaya (2001), which had also applied quantile regression methods to assess differential responses but with cross-sectional data and not addressing unobserved selection, this study used linked data on newborns and mothers to control for unobserved heterogeneity by embedding correlated random effects (at the level of the mother) within the quantile regression framework. This study also found a counter-intuitive result that third trimester care (versus first trimester care) increased birthweight by 62 to 72 grams at the 10th and 25th percentiles of birthweight (but had no effects at higher percentiles).

Evans and Lien (2005) exploited what economists often refer to as a "natural experiment" - a random shock that, in this case, had the potential to limit prenatal care. Specifically, the authors used birth records from Allegheny County, PA from 1990-1994 to investigate the effects of the number of prenatal care visits on birthweight and gestational age by exploiting plausibly exogenous variation in care as a result of a bus strike in Pittsburgh, Pennsylvania. Based on reduced visits associated with the strike, they inferred that the number of prenatal visits did not significantly affect birthweight for all pregnant women. However, they found some suggestive evidence of an effect size of 57 grams for women early in their pregnancies (i.e., one less prenatal care visit led to a 57 gram reduction in 
birthweight, suggesting that one more prenatal care visit increased birthweight by 57 grams in this group).

Reichman et al. (2009) used a unique and rich data source that allowed them to include many typically unobserved but theoretically important variables that affect the demand for prenatal care in OLS models of the production of infant health, including wantedness of the child and detailed measures of the mothers' prenatal physical and mental health. The data were from the Fragile Families and Child Wellbeing (FFCWB) study of U.S. urban births in 1998-2000, from which individual-level postpartum survey records were linked to the mothers' and infants' medical records from the birth hospitalization. The survey data included rich sociodemographic measures for both mothers and fathers, including religious attendance, non-marital cohabitation, and length of parents' relationship, and the medical record module included detailed information from the mother's prenatal care records and the infants' newborn records. The FFCWB study oversampled non-marital births by design in order to study a policyrelevant population, whereas administrative birth records (which were used in many of the previously discussed studies) are available for all births in the U.S. However, the sociodemographic information is much more limited in birth records than in the FFCWB and the medical information in birth records has low rates of accuracy (Reichman and Hade 2001). The authors found, using self-reports of first trimester care from the mother's postpartum survey, that first trimester prenatal care (versus later than first trimester care) increased birthweight by about 50 grams, reduced low birthweight by 2 percentage points, and reduced abnormal infant health conditions (a composite measure coded by a professional from the newborns' medical charts) by 3 percentage points. However, they found no effects of first trimester care on any of the birth outcomes using information on the timing of initiation of prenatal care from the medical records, which represents the gold standard source of such information.

Finally, we now consider the broader literature that has used RCTs in developed countries. We focus on meta-analyses, all of which focus on specific aspects of prenatal care. Withholding standard 
care would not be ethical, and there are therefore no published RCT studies focusing on timing of prenatal care initiation. Blondel and Breart (1995) reviewed eight RCTs that evaluated the effects of prenatal home visits and found no reductions in preterm birth. Carter et al. (2016) reviewed four studies comparing group versus standard prenatal care, and found no differences in preterm birth or neonatal intensive care admissions, while Lathrop (2013) reviewed three studies and found that group prenatal care (versus standard prenatal care) increased gestational age. Dowswell et al. (2018) covered four studies that investigated effects of a reduced-visits regimen and did not find compelling evidence that fewer visits increased the risk of preterm birth, small-for-gestational age, or low birthweight. Similarly, Carroli et al (2001) reviewed seven studies and found no effects of reduced visits on low birthweight. Finally, Fiscella (1995) reviewed eleven RCTs that evaluated the effects of enhanced (quantitatively and qualitatively more intensive) prenatal care on gestational age, birthweight, preterm birth, low birthweight, and small-for-gestational age, and found no statistically significant improvements in birth outcomes with the receipt of enhanced care. However, many of the studies in the Fiscella review, which covered a variety of years, settings, programs, and populations, were limited by a lack of statistical power. Overall, the available evidence from RCTs indicates small effects of variations in prenatal care visits and enhanced services on birth outcomes.

\section{Effect magnitudes}

It is difficult to compare estimates of the effects of prenatal care on birth outcomes across existing studies because they often used different measures of prenatal care and considered different birth outcomes. Even studies that seemingly should produce similar estimates often produce widely divergent findings. For example, two of the major studies used the same measures of prenatal care (months of delay) and infant health (birthweight) and studied older cohorts produced different estimates. Rosenzweig and Schultz (1988) found that each month of prenatal care delay reduced birthweight by about 91 grams, while Grossman and Joyce (1990) found that each month of care delay 
reduced birthweight -37 grams (this was significant) for blacks and -23 grams (this was insignificant) for whites. Effect magnitudes also often diverged even within the same study, depending on functional form or estimation method (Rosenzweig and Schultz 1988). Both of these studies found evidence of unobserved heterogeneity in prenatal care use.

Below, we condense the literature in Table 1 to provide ranges of magnitudes of effects of prenatal care on birth outcomes. We focus on input and outcome combinations for which there are at least two studies and, when there are several estimates, exclude those that are clearly outliers. Of the 25 studies we reviewed, many also estimated the effects of prenatal smoking, the leading known modifiable risk factor for adverse birth outcomes, and those findings are presented in Table 1. The average effect of smoking (some measured as smoking at all, others estimating effects of smoking a pack per day) across the studies that also focused on smoking was about 160 to 230 grams in birthweight, which corresponds to a 5 to $7 \%$ decrease. Only one study (Reichman et al. 2009) estimated effects of both prenatal care and smoking at the individual level, and that study found that smoking during pregnancy reduced low birthweight by 5-7 percentage points, while first trimester care did not increase birthweight using their preferred measure of first trimester care (from medical records) and by 2 percentage points using self-reported first trimester care (which the authors argued was likely an overestimate). The estimated effects of prenatal smoking on birthweight are less variable than those of prenatal care on birthweight, and the average effect sizes are much larger-providing useful context for interpreting the practical significance of the effect sizes for prenatal care on that outcome.

- First trimester care (versus not first trimester care) on low birthweight: Estimates varied from no effect to (perhaps) a 1 to $3.8 \%$ decrease.

- Prenatal care delay (months) on birthweight in grams: This was the combination with the greatest variability in estimates, which ranged from no effect to about 130 to 150 grams for 
each month of delay; the more recent studies indicate a narrower range of 0 to about 40 grams for each month of delay. These estimates are generally trivial compared to those for smoking.

- Number of prenatal care visits on birthweight: Estimates range from no effect to 46 grams per visit. The recommended number of prenatal visits for an uncomplicated pregnancy is about 15 (American Academy of Pediatrics/ American Congress of Obstetricians and Gynecologists 2012). For a healthy pregnancy, a one-month delay in the first 6 months of pregnancy would result in one fewer visit. Thus, the range of estimates here appears to be at odds with the bulk of the evidence on the effects of prenatal care delay on birthweight (synthesized above), with estimates of the effect of a one-month delay on birthweight in the triple digits.

- Effects across the distribution of infant health outcomes: This literature is still in its infancy, and the results are too inconsistent to draw any conclusions.

- Effects of enriched prenatal care: The two studies that focused on Medicaid enhanced prenatal care programs compared to standard Medicaid prenatal care found modest increases in average birthweight and more sizable reductions in low birthweight (on the order of 1.5 to 3.7 percentage points for some sub-samples) and very low birthweight (0.4 to 1.3 percentage points). Reichman and Florio (1996) estimated that only a small fraction of the effects appeared to be due to decreased prenatal care delay and inferred that it was other aspects of the enhanced prenatal care program that explained the observed effects.

- Effects of first trimester care on neonatal mortality: Zero to about 1-2\% reduction.

\section{Discussion}

This review indicates that the effects of prenatal care on birth outcomes are modest. Existing studies used a variety of different measures, techniques, and samples, producing estimates that are not straightforward to compare. That said, studies in the 1990s and beyond generally found smaller effect sizes than were found by Rosenzweig and Schultz for an earlier (pre-Medicaid expansion) cohort. It is 
plausible that the effects of prenatal care on birth outcomes changed over time (i.e., as prenatal care became more widely used as a result of the Medicaid eligibility expansions in the 1980s, the effects on birth outcomes may have become smaller as women most likely to benefit gained access to care). Rous et al. (2004) found some suggestive evidence of concavity and diminishing returns in the effects of prenatal care visits on birthweight. Figure 1 showed that about $8 \%$ of infants born in the U.S. in 1970 (close to the Rosenzweig and Schultz cohort) had mothers who initiated prenatal care after the second trimester of pregnancy, while the corresponding figure in 1999 was about 4\%_representing a decrease of 50 percent.

Studies that included multiple endogenous inputs (e.g., Rosenzweig and Schultz 1983, Li and Poirier 2003a\&b) and that had more ambitious modeling strategies tended to produce estimates that were the largest but not robust with respect to specification or alternative measures. For example, the finding in the Rosenzweig and Schultz study of a 52 gram reduction in birthweight for each month of prenatal care delay was based on a Cobb-Douglas production function, while a translog functional form indicated no significant effects. Li and Poirier (2003b), which estimated a simultaneous equations model with seven endogenous variables, found that first trimester care increased birthweight by 505 grams, which is enormous compared to all other estimates, and had less dramatic effects on gestational age. Studies that exploited variations in policies or natural experiments (e.g. Medicaid expansions, variations in Medicaid fees, a bus strike) tended to find smaller effects than earlier studies that relied on a host of state-level and/or individual-level instrumental variables. This difference in effect magnitudes may partly reflect differences in the populations studied, differences in the margins being affected, and how well the two match up within studies. For example, with multiple state- and individual-level instruments, it is unclear who the compliers are that are identifying the effect, which "local average treatment effect" or margin is being estimated, and how this margin compares with those being captured in studies that exploit policy variation or natural experiments. In addition, the choice of IVs and exclusion restrictions in 
the early studies, as well as in later studies that considered multiple endogenous inputs, was often questionable and possibly contributed to some of the inconsistencies across estimates.

The issue of self-reporting bias for prenatal care is very consequential for estimating the effects of prenatal care but has been largely ignored in the literature. Validation studies have shown that prenatal care use is over-reported in birth records (e.g., Reichman and Hade 2001). Only three of the 25 non-RCT studies we reviewed constructed measures of prenatal care from medical records, and comparisons of estimates using self-reported prenatal care versus prenatal care use from medical records in these studies indicated significant and moderate "effects" of prenatal care on birth outcomes only when using self-reported prenatal care. That is, when using measures of prenatal care from medical records, considered the "gold standard" source for prenatal care information, no significant effects of prenatal care on birth outcomes were apparent.

Heterogeneity of effects may be important, but such variations have not been sufficiently explored to allow for generalized inferences. For example, several of the studies found differential effects of prenatal care on birth outcomes by race and ethnicity, but patterns were inconsistent across studies. In addition, average effects across the population of births may not always be meaningful-e.g., for birthweight as an outcome. For example, Sonchak (2015), which was based on millions of births, found that an additional prenatal visit increased birthweight by about 23 grams, or $0.6 \%$, which is trivial compared to the estimates in the literature for prenatal smoking; however, that average effect may mask substantively important effects at critical margins. In this vein, the few studies that investigated effects of prenatal care on infant health across the (maternal or child) health distribution have produced seemingly conflicting results. Abrevaya and Dahl (2008) found a large (323 gram) negative effect of no prenatal care (compared to first trimester care) for infants in the lowest $10 \%$ of the birthweight distribution, but that initiating care in the second or third trimester (versus first trimester) increased birthweight by 27-63 grams. Conway and Deb (2005) found seemingly opposite results-that prenatal 
care improved birthweight for a latent class of "normal" pregnancies, which have a higher likelihood of being full-term and resulting in normal birthweight births, and the magnitude of their estimate suggests that first trimester care increased birthweight by 390 to 455 grams. In contrast, and seemingly more consistent with the findings of Abrevaya and Dahl, Mukhopadhyay and Wendel (2008) found that prenatal visits had a favorable effects on infant health (proxied by newborn hospital costs) for women with pre-existing health conditions.

Although the effects of prenatal care appear to be modest, it is important to consider the scope of prenatal care more broadly. First, the quality of prenatal care may be more important than the quantity. The Reichman and Florio (1996) study of augmented Medicaid prenatal care (versus standard Medicaid prenatal care), which included an increased number of visits, increased provider reimbursement, case coordination, integrated health support services, case managers, and community outreach, found some evidence of improvements in birth outcomes above and beyond what could plausibly be attributed to the timing of care initiation (although the effects could potentially reflect the increased number of visits). The effects were concentrated among black mothers and may reflect the integrated support, case coordination, and case management features of the program, which perhaps reduced stress from dealing with discrimination in the healthcare system as described anecdotally in a recent New York Times article on black infant mortality (Villarosa 2018). Additionally, prenatal care may operate through indirect channels, wherein greater or more intensive contact between expectant mothers and health care providers could lead to decreases (increases) in health-compromising (healthpromoting) behaviors such as smoking or better diet and nutrition. For example, it appears that some of the favorable effect of enhanced prenatal care on birth outcomes in the Reichman and Florio study reflected referrals to the WIC program (Reichman and Teitler 2003). Of note, if changes in health behaviors are a mechanism through which prenatal care improves birth outcomes, then studies that 
control for prenatal behaviors may underestimate the effects of prenatal care on infant health outcomes (depending on the timing of the measurement of the behaviors).

Second, prenatal care may be "too little too late" to improve birth outcomes for some women, who may enter pregnancy with a host of physical, mental, and psychosocial problems, the effects of which cannot be addressed within the confines of a pregnancy. Women's pre-pregnancy mental and physical health are important predictors of birth outcomes above and beyond pregnancy-related health (Almond, Currie, and Herrmann 2012; Reichman et al. 2009), suggesting that healthcare access and quality for women of reproductive age (and even young girls) is a more promising strategy than prenatal care for improving infant health. Furthermore, the availability of abortion services also appears to be an important predictor of infant health (e.g., Corman, Joyce and Grossman 1988; Joyce and Grossman 1990, Walker and Wallace 1998), suggesting the importance of access to family planning servicesideally as part of comprehensive and multifaceted health care. In other words, prenatal care should not start at conception.

Third, prenatal care may have beneficial effects not necessarily reflected in measures of birthweight or gestational age. Most of the studies reviewed here focused on birthweight- or gestational age-related outcomes. Although birthweight is a widely used and well-measured index of subsequent morbidity, it is not a direct measure of infant health. That is, many low birthweight children have no serious health problems (Reichman 2005) and not being low birthweight is no guarantee of favorable health status at birth. Thus, it is possible that using birthweight or low birthweight to proxy infant health can lead to incorrect inferences about the effects of prenatal care on infant health. Reichman et al. (2009) complemented birthweight outcomes with a direct measure of infant morbidity and found similar results vis-à-vis the effects of first trimester care (i.e., no effects using prenatal care from medical records), which was validating. Additionally, as pointed out by Grossman (2017) and others, prenatal 
care could identify high-risk deliveries and refer those women to deliver in hospitals with high-level neonatology, reducing neonatal deaths and morbidities.

Fourth, prenatal care can have beneficial effects not necessarily reflected in infant health. Reichman et al. (2010), using a multi-pronged approach to address the potential endogeneity of the timing of prenatal care, found that first trimester prenatal care led to decreased maternal postpartum smoking, increased use of well-baby care, and possibly increased breastfeeding, which can favorably impact child health, and Teitler et al. (2012) found that late or inadequate prenatal care was associated with short subsequent birth intervals, which are associated with adverse perinatal outcomes. That said, Noonan et al. (2011), using rich linked survey and medical data, found no associations between prenatal care and four markers of child health at age 5-maternal-reported health status, asthma diagnosis, overweight, and height. Conway and Kutinova (2006) found that receiving early and adequate prenatal care led mothers to maintain a healthy postpartum weight and may have reduced lengthy maternal birth hospitalizations. Finally, benefits of prenatal care may take generations to become apparent. For example, Miller and Wherry (forthcoming) found that the expansions of Medicaid coverage for pregnant women and infants led to lower rates of chronic conditions and fewer hospitalizations related to diabetes and obesity among individuals who gained access to coverage in utero and during infancy.

Overall, although we conclude that the estimated effects of prenatal care on birth outcomes are modest at best, we argue that the question being asked may be too narrow. Implications that arise from this review and synthesis are that more attention should be paid to the characterization of infant health, characterization of the content and quality of prenatal care, potential heterogeneous effects, potential indirect effects, potential long-term effects, spillover effects (i.e., on mothers and their subsequent children), effects of pre-conceptional and lifetime care, and intergenerational effects. 


\section{References}

Abrevaya, J. (2001). The effects of demographics and maternal behavior on the distribution of birth outcomes. Empirical Economics, 26(1), 247-257.

Abrevaya, J., Dahl, C.M. (2008). The effects of birth inputs on birthweight. Journal of Business and Economic Statistics, 26(4), 379-397.

Alexander, G., Kotelchuck, M. (1996). Quantifying the adequacy of prenatal care: a comparison of indices. Public Health Reports, 111, 408-418.

Almond, D., Currie, J., Herrmann, M. (2012). From infant to mother: early disease environment and future maternal health. Labour Economics, 19(4), 475-483.

American Academy of Pediatrics/ American College of Obstetricians and Gynecologists. (2012). Guidelines for perinatal care, 7th ed. Elk Grove Village, IL: AAP: Washington, DC.

Blondel, B., Bréart, G. (1995). Home visits during pregnancy: consequences on pregnancy outcome, use of health services, and women's situations. Seminars in Perinatology, 19(4), 263-271.

Carroli, G., Villar, J., Piaggio, G., Khan-Neelofur, D., Gülmezoglu, M., Mugford, M., ..., WHO Antenatal Care Trial Research Group. (2001). WHO systematic review of randomised controlled trials of routine antenatal care. Lancet, 357(9268), 1565-1570.

Carter, E.B., Temming, L.A., Akin, J., Fowler, S., Macones, G.A., Colditz, G.A., Tuuli, M.G. (2016). Group prenatal care compared with traditional prenatal care: a systematic review and metaanalysis. Obstetrics and Gynecology, 128(3), 551.

Cnattingius S. (2004). The epidemiology of smoking during pregnancy: smoking prevalence, maternal characteristics, and pregnancy outcomes. Nicotine \& Tobacco Research, 6(Supplement 2), S125S140.

Conway, K.S., Deb, P. (2005). Is prenatal care really ineffective? or, is the 'devil' in the distribution? Journal of Health Economics, 24(3), 489-513.

Conway, K. S., Kutinova, A. (2006). Maternal health: does prenatal care make a difference? Health Economics, 15, 461-488.

Corman, H., Dave, D., Reichman, N.E. (forthcoming). Evolution of the infant health production function. Southern Economic Journal. Previous version available as National Bureau of Economic Research Working Paper No. 24131 (December 2017).

Corman, H., Joyce, T.J., Grossman, M. (1987). Birth outcome production function in the United States. Journal of Human Resources, 22(3), 339-360.

Corman, H., Joyce, T., Grossman, M. (1988). A cost-effectiveness analysis of strategies to reduce infant mortality. Medical Care, 26(4), 348-360.

Currie, J., Gruber, J. (1996). Saving babies: the efficacy and cost of recent changes in the Medicaid eligibility of pregnant women. Journal of Political Economy, 104(6), 1263-1296.

Dowswell, T., Carroli, G., Duley, L., Gates, S., Gülmezoglu, A. M., Khan-Neelofur, D., Piaggio, G.G. (2010). Alternative versus standard packages of antenatal care for low-risk pregnancy. The Cochrane Database of Systematic Reviews, 6(10),CD000934.

Evans, W.N., Lien, D.S. (2005). The benefits of prenatal care: evidence from the PAT bus strike. Journal of Econometrics, 125(1-2), 207-239.

Fiscella, K. (1995). Does prenatal care improve birth outcomes? A critical review. Obstetrics \& Gynecology, 85(3), 468-479.

Frank, R.G. , Strobino, D.M., Salkever, D.S., Jackson, C.A. (1992). Updated estimates of the impact of prenatal care on birthweight outcomes by race. Journal of Human Resources, 27(4), 629-642.

Gray, B. (2001). Do Medicaid physician fees for prenatal services affect birth outcomes? Journal of Health Economics, 20(4), 571-590. 
Grossman, M. (1972). On the concept of health capital and the demand for health. Journal of Political Economy, 80(2), 223-255.

Grossman, M. (2017). Determinants of health: an economic perspective. Columbia University Press. Afterword to part 3, 450-466.

Grossman, M., Joyce, T.J. (1990). Unobservables, pregnancy resolutions, and birth weight production functions in New York City. Journal of Political Economy, 98(5), 983-1007.

Hamilton, B.H. (2001). Estimating treatment effects in randomized clinical trials with non-compliance: the impact of maternal smoking on birthweight. Health Economics, 10(5), 399-410.

Institute of Medicine (U.S.) Committee to Study Outreach for Prenatal Care; Brown S.S., editor. Prenatal Care: Reaching Mothers, Reaching Infants. Washington (DC): National Academies Press (U.S.); 1988.

Jones, A.M. (1991). An econometric investigation of low birth weight in the United States. Journal of Health Economics, 10(1), 81-99.

Joyce, T. (1994). Self-selection, prenatal care, and birthweight among Blacks, Whites, and Hispanics in New York City. Journal of Human Resources, 29(3), 762-794.

Joyce, T. (1999). Impact of augmented prenatal care on birth outcomes of Medicaid recipients in New York City. Journal of Health Economics, 18(1), 31-67.

Joyce, T., Grossman, M. (1990). The dynamic relationship between low birthweight and induced abortion in New York City: an aggregate time-series analysis. Journal of Health Economics, 9(3), 273-288.

Kogan, M. D., Martin, J. A., Alexander, G. R., Kotelchuck, M., Ventura, S. J., Frigoletto, F. D. (1998). The changing pattern of prenatal care utilization in the United States, 1981-1995, using different prenatal care indices. Journal of the American Medical Association, 279, 1623-1628.

Li, K., Poirier, D. J. (2003a). An econometric model of birth inputs and outputs for Native Americans. Journal of Econometrics, 113(2), 337-361.

Li, K., Poirier, D. J. (2003b). Bayesian analysis of an econometric model of birth inputs and outputs. Journal of Population Economics, 16(3), 597-625.

Liu, G.G. (1998). Birth outcomes and the effectiveness of prenatal care. Health Services Research, 32(6), 805-823.

March of Dimes. (2009). During your pregnancy: Prenatal care. Pregnancy and newborn health education center. http://www.marchofdimes.com/pnhec/159_513.asp.

Mukhopadhyay, S., Wendel, J., Lee, W., Yang, W. (2008). Analyzing the impact of prenatal care on infant health: do we have useful input and output measures? Economics Bulletin, 9(22), 1-14.

Mukhopadhyay, S., Wendel, J. (2008). Are prenatal care resources distributed efficiently across high-risk and low-risk mothers? International Journal of Health Care Finance and Economics, 8(3), 163179.

Miller, S, Wherry, L.R. (forthcoming). The long-term effects of early life Medicaid coverage. Journal of Human Resources; published ahead of print January 30, 2018. http://jhr.uwpress.org/content/early/2018/01/25/jhr.54.3.0816.8173R1.abstract

Noonan, K., Corman, H., Schwartz-Soicher, O., Reichman, N.E. (2013). Effects of Prenatal Care on Child Health at Age 5. Maternal and Child Health Journal ,17(2), 189-199.

OECD Family Database. Chart CO1.3A. Retrieved on 7/11/18 from: http://www.oecd.org/els/family/database.htm

Osterman, M.J.K., Martin, J.A. Timing and adequacy of prenatal care in the United States, 2016. (2018). National Vital Statistics Reports, 67(3). Hyattsville, MD: National Center for Health Statistics.

Pagnini, D., Reichman, N.E. (2000). Psychosocial factors and the timing of prenatal care among women in New Jersey's HealthStart Program. Family Planning Perspectives, 32(2), 56-64.

Reichman, N. (2005). Low birth weight and school readiness. The Future of Children, 15(1), 91-116. 
Reichman, N.E., Florio, M.J. (1996). The effects of enriched prenatal care services on Medicaid birth outcomes in New Jersey. Journal of Health Economics, 15(4), 455-476.

Reichman, N.E., Corman, H., Noonan, K., Dave, D. (2009). Infant health production functions: what a difference the data make. Health Economics, 18(7), 761-782.

Reichman, N.E., Corman, H., Noonan, K., Schwartz-Soicher, O. (2010). Effects of prenatal care on maternal postpartum behaviors. Review of Economics of the Household, 8(2), 171-197.

Reichman, N.E., Hade, E. (2001). Validation of birth certificate data: a study of women in New Jersey's HealthStart Program. Annals of Epidemiology, 11(3), 186-193.

Reichman, N.E., Teitler, J.O. (2003). Effects of psychosocial risk factors and prenatal interventions on birth weight: evidence From New Jersey's HealthStart Program. Perspectives on Sexual and Reproductive Health, 35(3), 130-137.

Rosenzweig, M.R., Schultz, T.P. (1983). Estimating a household production function: heterogeneity, the demand for health inputs, and their effects on birth weight. Journal of Political Economy, 91(5), 723-746.

Rosenzweig, M.R., Schultz, T.P. (1988). The stability of household production technology: A replication. The Journal of Human Resources, 23(4), 535-549.

Rous, J.J., Jewell, R.T., Brown, R.W. (2004). The effect of prenatal care on birthweight: a full-information maximum likelihood approach. Health Economics, 13(3), 251-264.

Schappert, S.M. (1997). Ambulatory care visits to physician's offices, hospital outpatient departments, and emergency departments: United States, 1996. Vital Health Stat, 13, 1-37.

Sonchak, L. (2015). Medicaid reimbursement, prenatal care and infant health. Journal of Health Economics, 44, 10-24.

Teitler, J., Das, D., Kruse, L., Reichman, N.E. (2012). Prenatal care and subsequent birth intervals. Perspectives on Sexual and Reproductive Health, 44(1), 13-21.

Villarosa, L. Why America's black mothers and babies are in a life-or-death crisis: The answer to the disparity in death rates has everything to do with the lived experience of being a black woman in America. New York Times. April 11, 2018. https://www.nytimes.com/2018/04/11/magazine/black-mothers-babies-death-maternalmortality.html

Walker, M.B., Wallace, S. (1998). The implications of current policies on the production of infant health. Applied Economics, 30(9), 1177-1186.

Warner, G. (1998). Birthweight productivity of prenatal care. Southern Economic Journal, 65(1), 42-63.

Warner, G. L. (1995). Prenatal care demand and birthweight production of black mothers. The American Economic Review, 85(2), 132-137.

World Health Organization (WHO). WHO recommendations on prevention and management of tobacco use and second-hand smoke exposure in pregnancy. Geneva: World Health Organization;2013 
Figure 1: Percentages of Births with First Trimester Prenatal Care, United States, 1970-2003

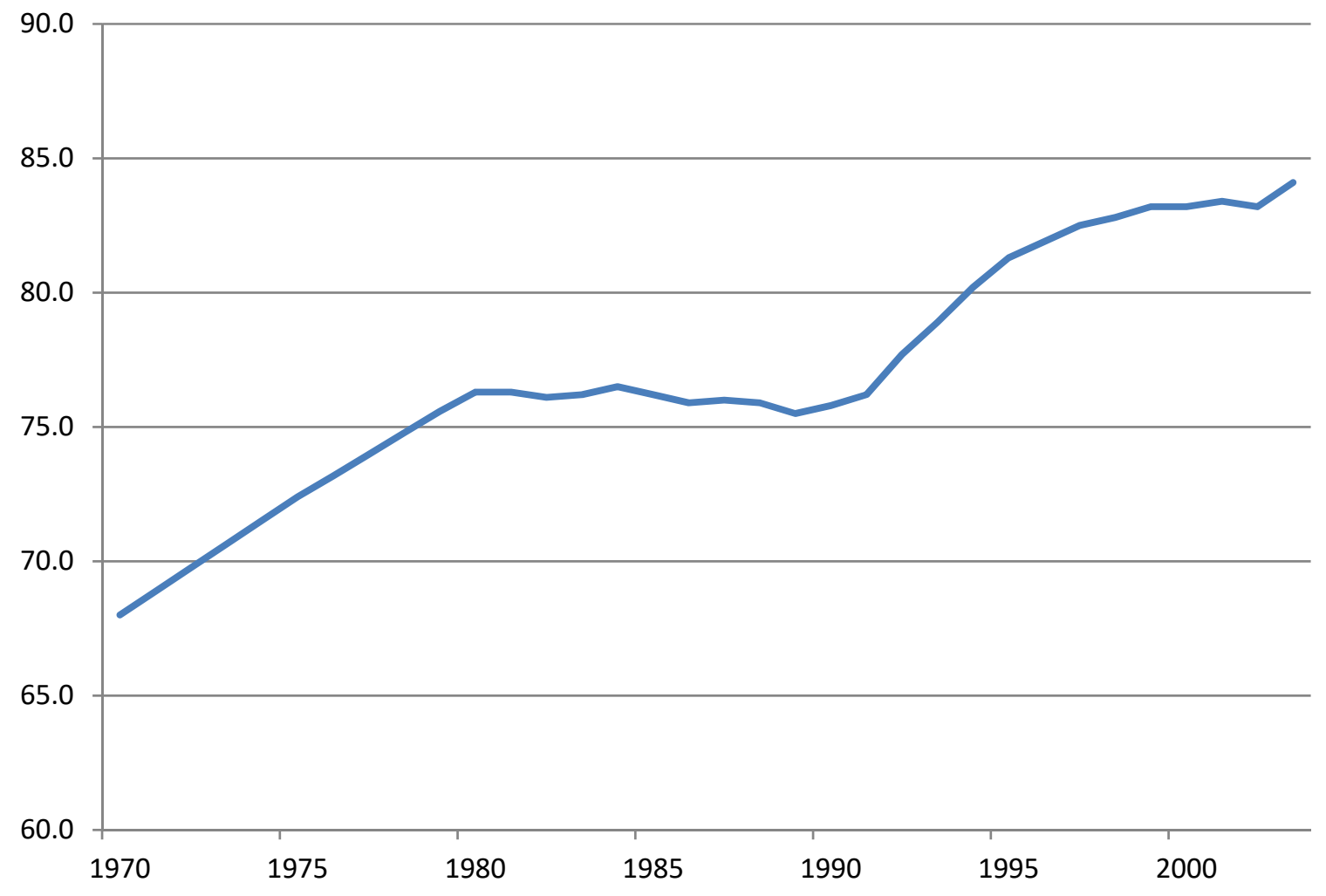

Notes: 1971-1974 and 1976-1979 data are interpolated; after 2003, reporting of prenatal care was changed so that data are not comparable after that year.

Sources of Data (all accessed on 7/10/18):

1970, 1975, 1995-1999: https://www.cdc.gov/nchs/data/data acces files/hus01cht.pdf

980-1994: https://www.cdc.gov/nchs/data/series/sr 21/sr21 054.pdf

2000-2003: Annual National Vital Statistics Reports: Births, Final Report 
Figure 2: Percentages of Births with Third Trimester or No Prenatal Care, United States, 1970-2003

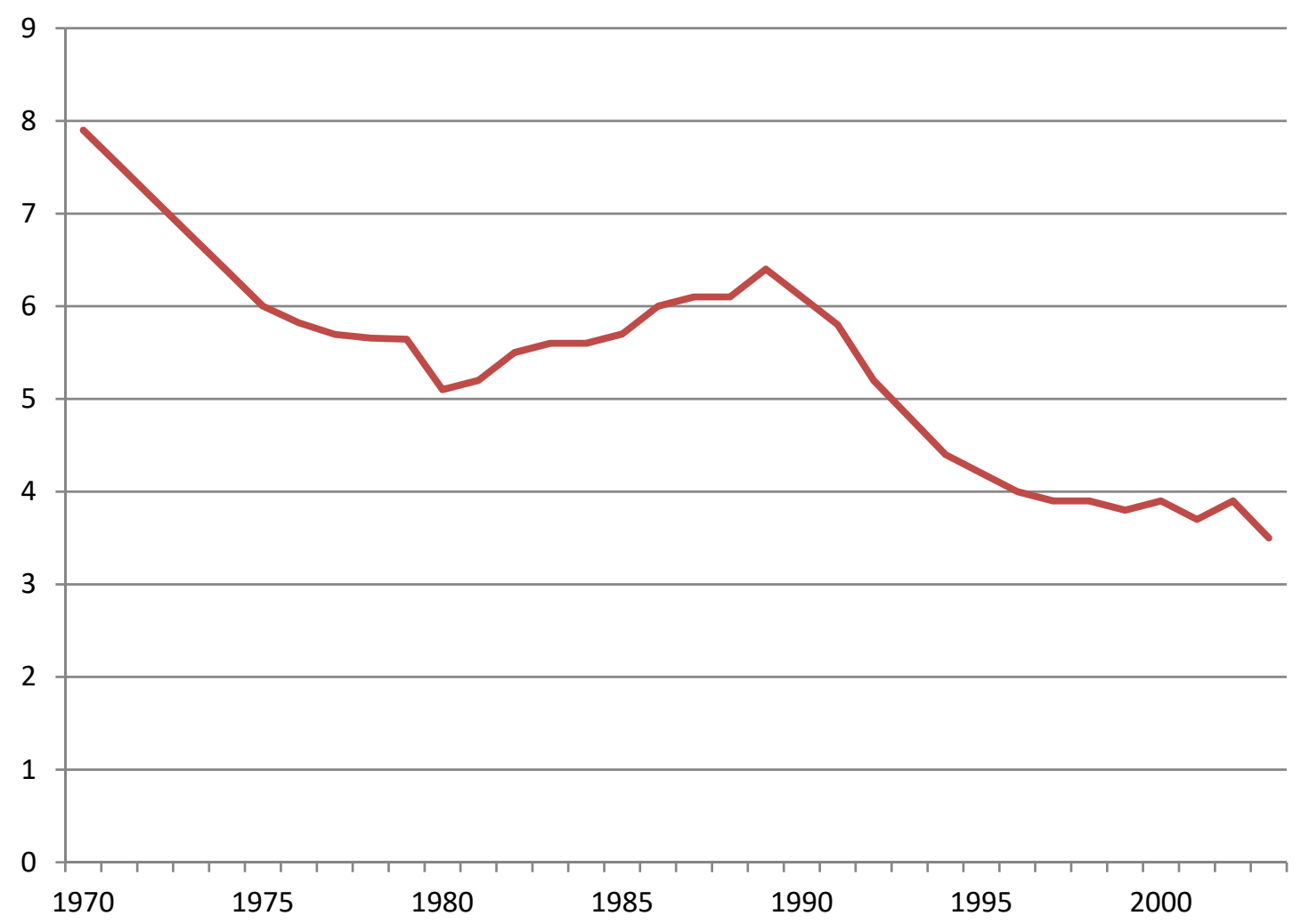

Notes: $1971-1974$ and 1976-1979 data are interpolated; after 2003, reporting of prenatal care was changed so that data are not comparable after that year.

Sources of Data (all accessed on 7/10/18):

1970, 1975, 1995-1999: https://www.cdc.gov/nchs/data/data_acces_files/hus01cht.pdf

980-1994: https://www.cdc.gov/nchs/data/series/sr_21/sr21_054.pdf

2000-2003: Annual National Vital Statistics Reports: Births, Final Report 
Figure 3: Percentages of Infants that were Low Birthweight, United States, 1970-2015

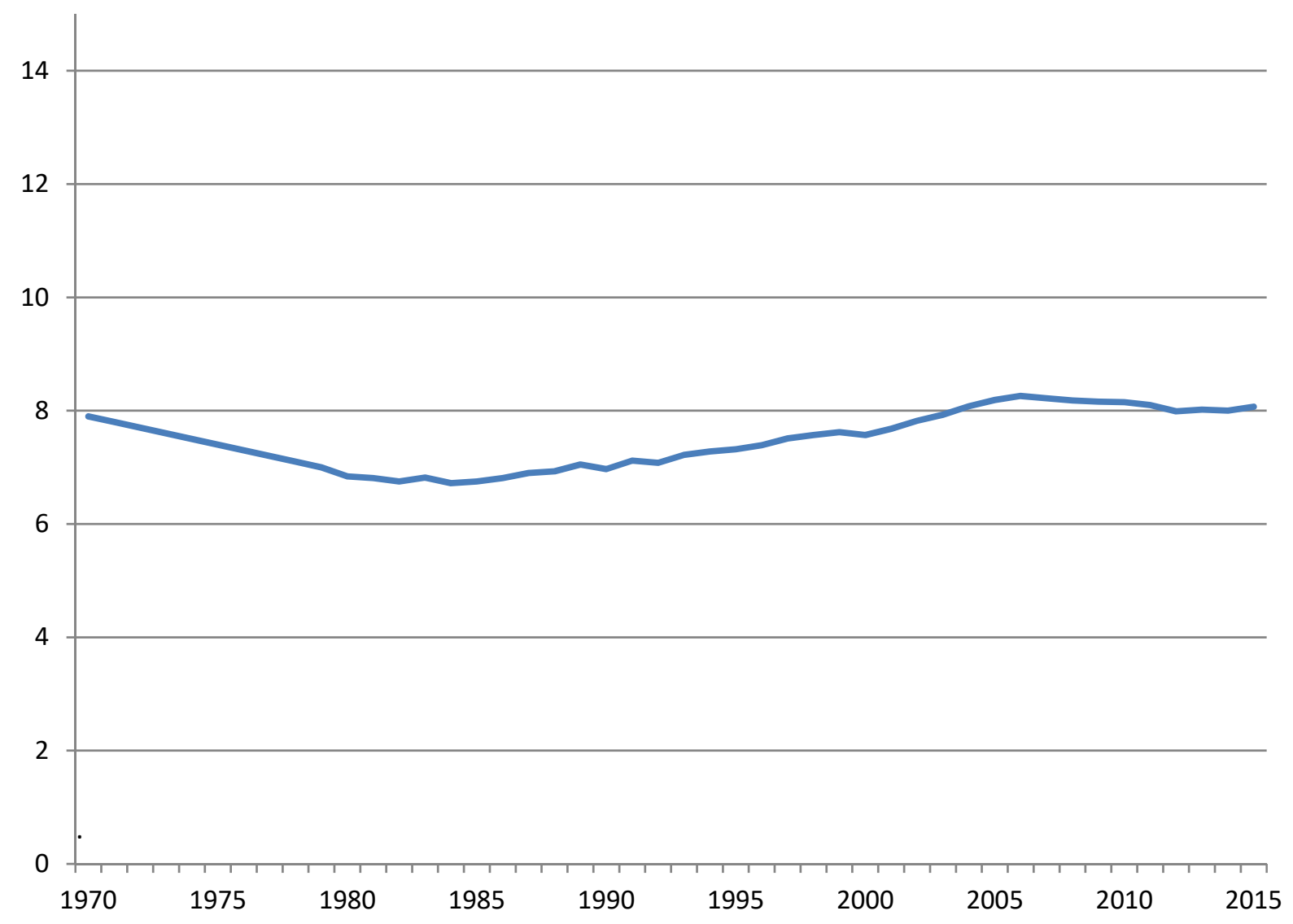

Notes: Data for 1971-1974 and 1975-1979 are interpolated; low birthweight is defined as less than 2500 grams

Data Source: Health, United States, 2016 - Individual Charts and Tables: Spreadsheet, PDF, and PowerPoint files

https://www.cdc.gov/nchs/hus/contents2016.htm\#005 (accessed on 7/10/18) 


\begin{tabular}{|c|c|c|c|c|c|c|}
\hline \# & Article & $\begin{array}{l}\text { Measure(s) of } \\
\text { Prenatal Care }\end{array}$ & $\begin{array}{l}\text { Birth } \\
\text { Outcome(s) }\end{array}$ & Data Source & Method(s) & Findings \\
\hline 1 & $\begin{array}{l}\text { Rosenzweig, M.R., } \\
\text { Schultz, T P. (1983). } \\
\text { Estimating a household } \\
\text { production function: } \\
\text { heterogeneity, the } \\
\text { demand for health } \\
\text { inputs, and their effects } \\
\text { on birth weight. Journal } \\
\text { of Political Economy, } \\
91(5), 723-746 .\end{array}$ & $\begin{array}{l}\text { (Ln) months } \\
\text { delayed } \\
\text { prenatal care }\end{array}$ & $\begin{array}{l}\text { Individual-level } \\
\text { BW and GA- } \\
\text { related } \\
\text { outcomes: } \\
\text { Ln BW; } \\
\text { BW/Predicted } \\
\text { BW based on GA }\end{array}$ & $\begin{array}{l}\text { National } \\
\text { Natality } \\
\text { Followback } \\
\text { Survey, 1967- } \\
69\end{array}$ & $\begin{array}{l}\text { IV } \\
\text { Identifiers (for } 4 \\
\text { endogenous inputs, } \\
\text { including prenatal care): } \\
\text { Parents' education, } \\
\text { income, and } 15 \text { area- } \\
\text { level measures capturing } \\
\text { input and good prices, } \\
\text { provider supply, public } \\
\text { spending and labor } \\
\text { market conditions }\end{array}$ & $\begin{array}{l}\text { - } 10 \% \text { increase in months of prenatal care delay } \\
\text { reduced BW by } 0.68 \% \text { (from their preferred } \\
\text { specification: Cobb Douglas, } 2 \text { SLS) } \\
\text { - Effect sizes imply that a } 5 \text { month delay reduces } \\
\text { BW by between } 260 \text { - } 410 \text { grams. } \\
\text { - } 2 \text { SLS elasticity estimates are } 40 \text { times OLS } \\
\text { estimates (latter not statistically significant); } \\
\text { other specification (translog) produced } \\
\text { insignificant results } \\
\text { - Prenatal care was never significant in predicting } \\
\text { small-for-GA } \\
\text { - Prenatal smoking reduced BW by } 230 \text { grams } \\
\text { (nonsmoker versus average smoker) }\end{array}$ \\
\hline 2 & $\begin{array}{l}\text { Corman, H., Joyce, T.J., } \\
\text { Grossman, M. (1987). } \\
\text { Birth outcome } \\
\text { production function in } \\
\text { the United States. } \\
\text { Journal of Human } \\
\text { Resources, 22(3), 339- } \\
360 .\end{array}$ & $\begin{array}{l}\text { \% first trimester } \\
\text { prenatal care }\end{array}$ & $\begin{array}{l}\text { County-level } \\
\text { neonatal } \\
\text { mortality, LBW } \\
\text { (3 yr. average) }\end{array}$ & $\begin{array}{l}\text { Natality and } \\
\text { mortality data, } \\
\text { U.S., 1976- } \\
1978\end{array}$ & $\begin{array}{l}\text { IV } \\
\text { Identifiers (for prenatal } \\
\text { care and other endog. } \\
\text { Inputs): } 7 \text { area-level } \\
\text { measures plus Medicaid } \\
\text { availability and } \\
\text { generosity measures }\end{array}$ & $\begin{array}{l}\text { - } 1 \text { percentage point increase in women who } \\
\text { received first trimester prenatal care reduced } \\
\text { neonatal mortality by } 1 \% \text { for both blacks and } \\
\text { whites (2SLS results) } \\
\text { - For whites, 2SLS effects < twice corresponding } \\
\text { OLS estimates; for blacks, 2SLS } 4 \text { times > OLS } \\
\text { estimates } \\
\text { - A one unit increase in average daily number of } \\
\text { cigarettes per capita in state (mean about } 7.4 \\
\text { cigarettes per day) increased neonatal mortality } \\
\text { by } 6 \% \text { for blacks and whites in } 2 S L S \text { specification } \\
\text { - For whites, OLS result for smoking similar to } \\
\text { 2SLS; for blacks. 2SLS estimates about } 75 \% \\
\text { larger }\end{array}$ \\
\hline 3 & $\begin{array}{l}\text { Rosenzweig, M R., } \\
\text { Schultz, T.P. (1988). } \\
\text { The stability of } \\
\text { household production } \\
\text { technology: A } \\
\text { replication. The Journal } \\
\text { of Human }\end{array}$ & $\begin{array}{l}\text { (Ln) months } \\
\text { delayed } \\
\text { prenatal care }\end{array}$ & $\begin{array}{l}\text { Individual-level } \\
\text { BW }\end{array}$ & $\begin{array}{l}\text { National } \\
\text { Natality } \\
\text { Followback } \\
\text { Survey, 1967- } \\
69, \text { plus } 1980\end{array}$ & Same as \#1 above & $\begin{array}{l}\text { - } 1 \text { month delay in prenatal care reduced BW by } \\
40-91 \text { grams } \\
\text { - Smoking } 14 \text { cigarettes per day reduced } \\
\text { birthweight by 112-227 grams }\end{array}$ \\
\hline
\end{tabular}




\begin{tabular}{|c|c|c|c|c|c|c|}
\hline \# & Article & $\begin{array}{l}\text { Measure(s) of } \\
\text { Prenatal Care }\end{array}$ & $\begin{array}{l}\text { Birth } \\
\text { Outcome(s) }\end{array}$ & Data Source & Method(s) & Findings \\
\hline & $\begin{array}{l}\text { Resources, 23(4), 535- } \\
549 .\end{array}$ & & & & & \\
\hline 4 & $\begin{array}{l}\text { Grossman, M., Joyce, T. } \\
\text { J. (1990). } \\
\text { Unobservables, } \\
\text { pregnancy resolutions, } \\
\text { and birth weight } \\
\text { production functions in } \\
\text { New York City. Journal } \\
\text { of Political Economy, } \\
\text { 98(5), 983-1007. }\end{array}$ & $\begin{array}{l}\text { Months of } \\
\text { prenatal care } \\
\text { delay }\end{array}$ & $\begin{array}{l}\text { Individual-level } \\
\text { BW }\end{array}$ & $\begin{array}{l}\text { Birth records, } \\
\text { NYC, } 1984\end{array}$ & $\begin{array}{l}\text { IV w/ sample selection } \\
\text { Identifiers for prenatal } \\
\text { care: prenatal care clinic } \\
\text { and WIC center } \\
\text { availability, poverty, } \\
\text { Medicaid and self-pay } \\
\text { status } \\
\text { Identifiers in sample } \\
\text { selection model: } \\
\text { abortion providers and } \\
\text { family planning clinics, } \\
\text { spontaneous and } \\
\text { induced abortions }\end{array}$ & $\begin{array}{l}\text { - From preferred specification-sample selection } \\
\text { (birth probability) plus 2SLS for prenatal care: } \\
\text { Each month of prenatal care delay led to a (not } \\
\text { statistically significant) } 23 \text { gram reduction in BW } \\
\text { for whites and a (statistically significant) } 37 \\
\text { gram reduction in BW for blacks } \\
\text { - From selection model without 2SLS: } \\
\text { Corresponding estimates were } 4 \text { grams for } \\
\text { whites and } 12 \text { grams for blacks } \\
\text { - From OLS specification: Estimates similar to } \\
\text { those from selection specification } \\
\text { - 2SLS estimates 3-6 times larger than OLS } \\
\text { estimates } \\
\text { - Smoking (vs. not smoking) leads to a } 42-44 \\
\text { gram reduction in BW for whites and a 187-189 } \\
\text { gram reduction in BW for blacks; estimates } \\
\text { stable across specifications }\end{array}$ \\
\hline 5 & $\begin{array}{l}\text { Jones, A.M. (1991). An } \\
\text { econometric } \\
\text { investigation of low } \\
\text { birth weight in the } \\
\text { United States. Journal } \\
\text { of Health Economics, } \\
\text { 10(1), 81-99. }\end{array}$ & $\begin{array}{l}\text { \% infants born } \\
\text { to women who } \\
\text { received first } \\
\text { trimester } \\
\text { prenatal care }\end{array}$ & State-level LBW & $\begin{array}{l}\text { Children's } \\
\text { Defense Fund } \\
\text { publication, } \\
1984\end{array}$ & OLS & $\begin{array}{l}\text { - First-trimester prenatal care was negatively } \\
\text { associated with LBW, with unstable and very } \\
\text { small magnitude effects } \\
\text { - Range of estimates: }-0.005 \text { to } 0.018 \text { ppt., or } \\
\text { elasticities of }-0.03 \text { to }-0.26 \\
\text { - Association was significant only for whites }\end{array}$ \\
\hline 6 & $\begin{array}{l}\text { Frank, R.G. , Strobino, } \\
\text { D.M., Salkever, D.S., } \\
\text { Jackson, C.A. (1992). } \\
\text { Updated estimates of } \\
\text { the impact of prenatal } \\
\text { care on birthweight } \\
\text { outcomes by race. } \\
\text { Journal of Human }\end{array}$ & $\begin{array}{l}\% \text { infants born } \\
\text { to women who } \\
\text { received first } \\
\text { trimester } \\
\text { prenatal care }\end{array}$ & $\begin{array}{l}\text { County-level } \\
\text { LBW }\end{array}$ & $\begin{array}{l}\text { Natality data, } \\
\text { U.S., 1975- } \\
1984\end{array}$ & $\begin{array}{l}\text { Fixed effects (pooled, } \\
\text { time series, cross- } \\
\text { sectional study) }\end{array}$ & $\begin{array}{l}\text { - Outcome elasticities of first trimester prenatal } \\
\text { care were }-0.10 \text { to }-0.11 ; 1 \text { ppt increase in first } \\
\text { trimester care led to reduction in LBW of } .007 \\
\text { ppt for whites and } 0.018 \text { ppt for blacks }\end{array}$ \\
\hline
\end{tabular}




\begin{tabular}{|c|c|c|c|c|c|c|}
\hline$\#$ & Article & $\begin{array}{l}\text { Measure(s) of } \\
\text { Prenatal Care }\end{array}$ & $\begin{array}{l}\text { Birth } \\
\text { Outcome(s) }\end{array}$ & Data Source & Method(s) & Findings \\
\hline & $\begin{array}{l}\text { Resources, 27(4), 629- } \\
642 .\end{array}$ & & & & & \\
\hline 7 & $\begin{array}{l}\text { Joyce, T. (1994). Self- } \\
\text { selection, prenatal } \\
\text { care, and birthweight } \\
\text { among Blacks, Whites, } \\
\text { and Hispanics in New } \\
\text { York City. Journal of } \\
\text { Human Resources, } \\
29(3), 762-794 .\end{array}$ & $\begin{array}{l}\text { Inadequate, } \\
\text { intermediate, } \\
\text { or adequate } \\
\text { prenatal care } \\
\text { using modified } \\
\text { Kessner index }\end{array}$ & $\begin{array}{l}\text { Individual-level } \\
\text { BW }\end{array}$ & $\begin{array}{l}\text { Birth records, } \\
\text { NYC, } 1984\end{array}$ & $\begin{array}{l}\text { Endogenous switching } \\
\text { and IV models } \\
\text { Identifiers for prenatal } \\
\text { care: Insurance type; } \\
\text { area poverty; measures } \\
\text { of area availability of } \\
\text { prenatal care clinics, } \\
\text { family planning clinics, } \\
\text { WIC centers, abortion } \\
\text { providers, maternal } \\
\text { schooling, ethnicity (in } \\
\text { Hispanic equation) }\end{array}$ & $\begin{array}{l}\text { - Adequate (vs. inadequate) care led to increases } \\
\text { in birthweight of } 151 \text { grams for blacks, } 288 \\
\text { grams for whites, and } 229 \text { grams for Hispanics } \\
\text { (from preferred specification, which only } \\
\text { treated prenatal care as endogenous whereas } \\
\text { other specifications treated multiple inputs as } \\
\text { endogenous) } \\
\text { - Very modest effects between intermediate and } \\
\text { adequate care ( } 21 \text { grams for whites, } 11 \text { grams } \\
\text { for blacks, } 46 \text { grams for Hispanics); larger } \\
\text { effects between inadequate and intermediate } \\
\text { care } \\
\text { - IV-based two-stage effect sizes about } 3 \text { times } \\
\text { higher than OLS estimates for blacks and } \\
\text { Hispanics and about } 43 \% \text { higher for whites }\end{array}$ \\
\hline 8 & $\begin{array}{l}\text { Warner, G. L. (1995). } \\
\text { Prenatal care demand } \\
\text { and birthweight } \\
\text { production of black } \\
\text { mothers. The American } \\
\text { Economic Review, } \\
85(2), 132-137 .\end{array}$ & $\begin{array}{l}\text { Days of } \\
\text { prenatal care } \\
\text { delay; number } \\
\text { of prenatal } \\
\text { visits adjusted } \\
\text { for GA }\end{array}$ & $\begin{array}{l}\text { Individual-level } \\
\text { BW, GA }\end{array}$ & $\begin{array}{l}\text { Birth records, } \\
\text { NYC, 1980- } \\
1990 \\
\text { (black women } \\
\text { only) }\end{array}$ & $\begin{array}{l}\text { IV } \\
\text { Identifiers for prenatal } \\
\text { care: Method of } \\
\text { financing (Medicaid, self- } \\
\text { pay); father's education; } \\
\text { mother's age; health- } \\
\text { area variables: } \\
\text { availability of prenatal } \\
\text { and family planning } \\
\text { clinics; unemployment } \\
\text { and poverty rates; drug } \\
\text { deaths }\end{array}$ & $\begin{array}{l}\text { - Each additional day of prenatal care delay } \\
\text { reduced BW by } 1 \text { gram } \\
\text { - No significant effects of number of prenatal care } \\
\text { visits } \\
\text { - Suggestive evidence that delay of prenatal care } \\
\text { and number of visits may be substitutes (based } \\
\text { on interacted measure of visits divided by delay) } \\
\text { - First-trimester care initiation (reducing delay by } \\
\text { about } 75 \text { days) raises BW by } 170 \text { grams } \\
\text { (interpolated from authors' assumptions) } \\
\text { - No comparison OLS equations }\end{array}$ \\
\hline 9 & $\begin{array}{l}\text { Currie, J., Gruber, J. } \\
\text { (1996). Saving babies: } \\
\text { the efficacy and cost of } \\
\text { recent changes in the }\end{array}$ & $\begin{array}{l}\text { Medicaid } \\
\text { eligibility, which } \\
\text { could affect } \\
\text { prenatal care of }\end{array}$ & $\begin{array}{l}\text { State-year rates } \\
\text { of LBW and } \\
\text { infant mortality }\end{array}$ & $\begin{array}{l}\text { Natality and } \\
\text { mortality data, } \\
\text { U.S., 1979- } \\
1992\end{array}$ & $\begin{array}{l}\text { IV (endogenous variable } \\
\text { was Medicaid eligibility) }\end{array}$ & $\begin{array}{l}\text { - } 30 \text { ppt increase in pregnant women eligible for } \\
\text { Medicaid led to a } 1.9 \% \text { reduction in LBW } \\
\text { - The Medicaid expansions also reduced infant } \\
\text { mortality by } 8.5 \% \text {, but most of this reduction }\end{array}$ \\
\hline
\end{tabular}




\begin{tabular}{|c|c|c|c|c|c|c|}
\hline \# & Article & $\begin{array}{l}\text { Measure(s) of } \\
\text { Prenatal Care }\end{array}$ & $\begin{array}{l}\text { Birth } \\
\text { Outcome(s) }\end{array}$ & Data Source & Method(s) & Findings \\
\hline & $\begin{array}{l}\text { Medicaid eligibility of } \\
\text { pregnant women. } \\
\text { Journal of Political } \\
\text { Economy, 104(6), } \\
1263-1296 .\end{array}$ & $\begin{array}{l}\text { mothers or } \\
\text { postnatal care } \\
\text { of infants }\end{array}$ & & & $\begin{array}{l}\text { Identifier: Eligibility for } \\
\text { Medicaid according to } \\
\text { welfare rules of the state }\end{array}$ & $\begin{array}{l}\text { appeared to reflect increased use of postnatal } \\
\text { resources rather than prenatal care }\end{array}$ \\
\hline 10 & $\begin{array}{l}\text { Reichman, N.E., Florio, } \\
\text { M.J. (1996). The effects } \\
\text { of enriched prenatal } \\
\text { care services on } \\
\text { Medicaid birth } \\
\text { outcomes in New } \\
\text { Jersey. Journal of } \\
\text { Health Economics, } \\
\text { 15(4), 455-476. }\end{array}$ & $\begin{array}{l}\text { Enriched } \\
\text { prenatal care } \\
\text { for Medicaid } \\
\text { recipients } \\
\text { (program } \\
\text { included } \\
\text { increased \# } \\
\text { prenatal visits, } \\
\text { increased } \\
\text { provider } \\
\text { reimbursement, } \\
\text { case } \\
\text { coordination, } \\
\text { integrated } \\
\text { health support } \\
\text { services, case } \\
\text { managers, } \\
\text { community } \\
\text { outreach) }\end{array}$ & $\begin{array}{l}\text { Individual-level } \\
\text { BW, LBW, VLBW, } \\
\text { newborn } \\
\text { hospitalization } \\
\text { costs }\end{array}$ & $\begin{array}{l}\text { Linked } \\
\text { birth/death } \\
\text { and hospital } \\
\text { discharge } \\
\text { records, New } \\
\text { Jersey, } 1989 \text { \& } \\
1990\end{array}$ & $\begin{array}{l}\text { OLS and IV (tested and } \\
\text { found OLS to be } \\
\text { unbiased) } \\
\text { Identifiers for } \\
\text { HealthStart enrollment: } \\
\text { Numbers of HealthStart } \\
\text { providers in the } \\
\text { woman's city of } \\
\text { residence at least six } \\
\text { months before she gave } \\
\text { birth }\end{array}$ & $\begin{array}{l}\text { - Enriched prenatal care (compared to standard } \\
\text { Medicaid prenatal care) increased BW by } 55.7 \\
\text { grams, decreased newborn hospitalization costs } \\
\text { by } 6.9 \% \text {, decreased LBW by } 3.7 \text { ppts, and } \\
\text { decreased VLBW by .9 ppts for black women; } \\
\text { no evidence that enriched care was associated } \\
\text { with improved birth outcomes or lower costs } \\
\text { for white women (using preferred } \\
\text { specifications: OLS estimates) } \\
\text { - Of the } 55.7 \text { gram improvement, 5-15 grams } \\
\text { could be explained by prenatal care delay; } \\
\text { attributed rest of the effect to the program } \\
\text { itself }\end{array}$ \\
\hline 11 & $\begin{array}{l}\text { Liu, G.G. (1998). Birth } \\
\text { outcomes and the } \\
\text { effectiveness of } \\
\text { prenatal care. Health } \\
\text { Services Research, } \\
\text { 32(6), 805-823. }\end{array}$ & $\begin{array}{l}\text { Months of } \\
\text { prenatal care } \\
\text { delay }\end{array}$ & $\begin{array}{l}\text { Individual-level } \\
\text { BW }\end{array}$ & $\begin{array}{l}\text { Birth and } \\
\text { abortion } \\
\text { records, } \\
\text { Virginia, } 1984\end{array}$ & $\begin{array}{l}\text { IV w/ sample selection } \\
\text { model } \\
\text { Identifiers (unclear } \\
\text { which instrumental } \\
\text { variables were used } \\
\text { specifically for prenatal } \\
\text { care): Mother's marital } \\
\text { status; previous early } \\
\text { termination; area-level } \\
\text { abortion providers, } \\
\text { family planning clinics, }\end{array}$ & $\begin{array}{l}\text { - Each month of prenatal care delay resulted in a } \\
\text { 36-197 gram reduction in BW for urban blacks, } \\
\text { a 86-160 gram reduction for rural blacks, a 75- } \\
139 \text { gram reduction for urban whites, and a } \\
\text { 107-143 gram reduction for rural whites (using } \\
\text { preferred specifications: } 2 \text { SLS) } \\
\text { - 2SLS estimates 6-20+ times larger than OLS } \\
\text { estimates }\end{array}$ \\
\hline
\end{tabular}




\begin{tabular}{|c|c|c|c|c|c|c|}
\hline \# & Article & $\begin{array}{l}\text { Measure(s) of } \\
\text { Prenatal Care }\end{array}$ & $\begin{array}{l}\text { Birth } \\
\text { Outcome(s) }\end{array}$ & Data Source & Method(s) & Findings \\
\hline & & & & & $\begin{array}{l}\text { WIC clinics, and poverty } \\
\text { rates }\end{array}$ & \\
\hline 12 & $\begin{array}{l}\text { Warner, G. (1998). } \\
\text { Birthweight } \\
\text { productivity of prenatal } \\
\text { care. Southern } \\
\text { Economic Journal, } \\
65(1), 42-63 \text {. }\end{array}$ & $\begin{array}{l}\text { Weeks of } \\
\text { prenatal care } \\
\text { delay, } \\
\text { standardized } \\
\text { visits (based on } \\
\text { a term } \\
\text { pregnancy) }\end{array}$ & $\begin{array}{l}\text { Individual-level } \\
\text { BW }\end{array}$ & $\begin{array}{l}\text { National } \\
\text { Maternal \& } \\
\text { Infant Health } \\
\text { Survey } 1988\end{array}$ & $\begin{array}{l}\text { IV } \\
\text { Identifiers for prenatal } \\
\text { care: Household } \\
\text { income; source of } \\
\text { income; paternal } \\
\text { education; payment } \\
\text { source for prenatal care; } \\
\text { number of children in } \\
\text { the household; mother's } \\
\text { pregnancy work status; } \\
\text { urban residence; marital } \\
\text { / cohabitation status; } \\
\text { and } 6 \text { state-level } \\
\text { variables }\end{array}$ & $\begin{array}{l}\text { - Each additional prenatal visit increased BW by } \\
35 \text { grams for whites and } 46 \text { grams for blacks } \\
\text { (using linear 2SLS model with both delay in } \\
\text { weeks and number of visits included); inferred } \\
\text { that prenatal care increased BW through \# of } \\
\text { visits, not timing of initiation } \\
\text { - No OLS comparison equations } \\
\text { - Each cigarette smoked daily during pregnancy } \\
\text { reduced BW by 3-4 grams for whites and } 8 \\
\text { grams for blacks; each pack smoked daily } \\
\text { reduced BW by 60-80 grams for whites and } 160 \\
\text { grams for blacks }\end{array}$ \\
\hline 13 & $\begin{array}{l}\text { Joyce, T. (1999). Impact } \\
\text { of augmented prenatal } \\
\text { care on birth outcomes } \\
\text { of Medicaid recipients } \\
\text { in New York City. } \\
\text { Journal of Health } \\
\text { Economics, 18(1), 31- } \\
67 .\end{array}$ & $\begin{array}{l}\text { Augmented } \\
\text { prenatal care } \\
\text { for Medicaid } \\
\text { recipients (NY } \\
\text { State Prenatal } \\
\text { Care Assistance } \\
\text { Program; } \\
\text { PCAP)-similar } \\
\text { to NJ } \\
\text { HealthStart } \\
\text { program } \\
\text { (Reichman and } \\
\text { Florio 1996) }\end{array}$ & $\begin{array}{l}\text { Individual-level } \\
\text { BW, LBW, VLBW }\end{array}$ & $\begin{array}{l}\text { Linked } \\
\text { Medicaid } \\
\text { administrative } \\
\text { files and birth } \\
\text { records, NYC, } \\
1989-1991\end{array}$ & $\begin{array}{l}\text { IV } \\
\text { Identifiers for PCAP } \\
\text { enrollment: Numbers of } \\
\text { PCAP providers by health } \\
\text { area; interactions } \\
\text { between health district } \\
\text { and year; interactions } \\
\text { between hospital of } \\
\text { delivery and year }\end{array}$ & $\begin{array}{l}\text { - PCAP (compared to standard Medicaid prenatal } \\
\text { care) increased BW by } 33-83 \text { grams (depending } \\
\text { on year and subsample), decreased LBW by } 1.5- \\
3.7 \text { ppts, and decreased VLBW by } .4 \text { to } 1.3 \text { ppts. } \\
\text { (from OLS result); IV estimates were } \\
\text { insignificant and not robust }\end{array}$ \\
\hline 14 & $\begin{array}{l}\text { Abrevaya, J. (2001). The } \\
\text { effects of } \\
\text { demographics and } \\
\text { maternal behavior on } \\
\text { the distribution of birth } \\
\text { outcomes. }\end{array}$ & $\begin{array}{l}\text { Dummy } \\
\text { variables for } \\
\text { trimester } \\
\text { prenatal care } \\
\text { began: none, } \\
\text { third, or second }\end{array}$ & $\begin{array}{l}\text { Individual-level } \\
\text { BW }\end{array}$ & $\begin{array}{l}\text { Birth records, } \\
\text { U.S., } 1992 \text { \& } \\
1996\end{array}$ & Quantile regression & $\begin{array}{l}\text { - No prenatal care (compared to first trimester } \\
\text { care) reduced BW by } 389 \text { grams for those in } \\
\text { lowest } 10 \% \text { of BW distribution but only by 100- } \\
200 \text { grams at other points in the BW } \\
\text { distribution; other trimesters of care }\end{array}$ \\
\hline
\end{tabular}




\begin{tabular}{|c|c|c|c|c|c|c|}
\hline$\#$ & Article & $\begin{array}{l}\text { Measure(s) of } \\
\text { Prenatal Care }\end{array}$ & $\begin{array}{l}\text { Birth } \\
\text { Outcome(s) }\end{array}$ & Data Source & Method(s) & Findings \\
\hline & $\begin{array}{l}\text { Empirical Economics, } \\
26(1), 247-257 .\end{array}$ & $\begin{array}{l}\text { (compared to } \\
\text { first) }\end{array}$ & & & & $\begin{array}{l}\text { (compared to first) had small and inconsistently } \\
\text { signed effects on BW } \\
\text { - Average effect of any smoking on BW: } 161 \\
\text { grams; effect sizes ranged from } 171 \text { at lowest } \\
\text { quantile of BW to } 147 \text { at highest quantile }\end{array}$ \\
\hline 15 & $\begin{array}{l}\text { Gray, B. (2001). Do } \\
\text { Medicaid physician fees } \\
\text { for prenatal services } \\
\text { affect birth outcomes? } \\
\text { Journal of Health } \\
\text { Economics, 20(4), 571- } \\
590 .\end{array}$ & $\begin{array}{l}\text { Indirect effect } \\
\text { of first } \\
\text { trimester care } \\
\text { via Medicaid } \\
\text { reimbursement } \\
\text { rates }\end{array}$ & $\begin{array}{l}\text { Individual level } \\
\text { VLBW, LBW, } \\
\text { preterm birth, } \\
\text { infant death }\end{array}$ & $\begin{array}{l}\text { National } \\
\text { Maternal \& } \\
\text { Infant Health } \\
\text { Survey } 1988\end{array}$ & $\mathrm{DD}$ & $\begin{array}{l}\text { - } 10 \% \text { increase in relative Medicaid fees led to } 1 \\
\text { ppt increase in use of first trimester prenatal } \\
\text { care } \\
\text { - } 10 \% \text { increase in fees led to approximate } 0.1 \text { ppt } \\
\text { lower risk of VLBW and } 0.4 \text { ppt lower risk of } \\
\text { LBW among women on Medicaid ( } 4.5 \% \text { and } \\
3.8 \% \text {, respectively); no significant effects on } \\
\text { preterm birth or infant death } \\
\text { - Infer that the } 1 \text { ppt increase in use of first } \\
\text { trimester care led to } 0.1 \text { ppt lower risk of VLBW } \\
\text { and } 0.4 \text { ppt lower risk of LBW }\end{array}$ \\
\hline 16 & $\begin{array}{l}\text { Li, K., Poirier, D.J. } \\
\text { (2003a). An } \\
\text { econometric model of } \\
\text { birth inputs and } \\
\text { outputs for Native } \\
\text { Americans. Journal of } \\
\text { Econometrics, 113(2), } \\
\text { 337-361. }\end{array}$ & $\begin{array}{l}\text { First trimester } \\
\text { prenatal care }\end{array}$ & $\begin{array}{l}\text { Individual level } \\
\text { BW, GA, birth } \\
\text { length }\end{array}$ & $\begin{array}{l}\text { National } \\
\text { Longitudinal } \\
\text { Survey of } \\
\text { Youth 1979, } \\
\text { 1979-1994 }\end{array}$ & $\begin{array}{l}\text { Bayesian estimation of a } \\
\text { non-linear simultaneous } \\
\text { equations model, } \\
\text { comprising } 4 \text { inputs and } \\
3 \text { outputs } \\
\text { Identification is based on } \\
\text { numerous exclusions } \\
\text { restrictions (restricting } \\
\text { coefficients to be zero } \\
\text { for elements of both the } \\
\text { endogeneous and } \\
\text { exogenous variables); } \\
\text { identifying instruments } \\
\text { include region of } \\
\text { residence, calendar } \\
\text { time, Air Force } \\
\text { Qualifying Test (AFQT) } \\
\text { score, household }\end{array}$ & $\begin{array}{l}\text { - Prenatal care not found to have any substantive } \\
\text { or consistent effects on gestational age, birth } \\
\text { length, or birthweight } \\
\text { - Smoking also not found to have any substantive } \\
\text { effects on the birth outputs; point estimates } \\
\text { suggest that prenatal smoking reduces } \\
\text { gestation by } 0.2 \text { weeks, birth length by } 0.2 \mathrm{~cm} \text {, } \\
\text { and BW by } 114 \text { grams }\end{array}$ \\
\hline
\end{tabular}




\begin{tabular}{|c|c|c|c|c|c|c|}
\hline \# & Article & $\begin{array}{l}\text { Measure(s) of } \\
\text { Prenatal Care }\end{array}$ & $\begin{array}{l}\text { Birth } \\
\text { Outcome(s) }\end{array}$ & Data Source & Method(s) & Findings \\
\hline & & & & & $\begin{array}{l}\text { income, health } \\
\text { insurance, mother's } \\
\text { work status during } \\
\text { pregnancy, \# of adults in } \\
\text { households, cigarette } \\
\text { price, alcohol price, } \\
\text { medical services price, } \\
\text { food price }\end{array}$ & \\
\hline 17 & $\begin{array}{l}\text { Li, K., Poirier, D.J. } \\
\text { (2003b). Bayesian } \\
\text { analysis of an } \\
\text { econometric model of } \\
\text { birth inputs and } \\
\text { outputs. Journal of } \\
\text { Population Economics, } \\
\text { 16(3), 597-625. }\end{array}$ & $\begin{array}{l}\text { First trimester } \\
\text { prenatal care }\end{array}$ & $\begin{array}{l}\text { Individual-level } \\
\text { BW, GA, birth } \\
\text { length }\end{array}$ & $\begin{array}{l}\text { National } \\
\text { Longitudinal } \\
\text { Survey of } \\
\text { Youth 1979, } \\
\text { 1979-1994 }\end{array}$ & $\begin{array}{l}\text { Baysesian estimation of } \\
\text { a non-linear } \\
\text { simultaneous equations } \\
\text { model, comprising } 4 \\
\text { inputs and } 3 \text { outputs } \\
\text { Identification based on } \\
\text { numerous exclusions } \\
\text { restrictions (restricting } \\
\text { coefficients to be zero } \\
\text { for elements of both the } \\
\text { endogeneous and } \\
\text { exogenous variables); } \\
\text { identifying instruments } \\
\text { include region of } \\
\text { residence, calendar } \\
\text { time, AFQT score, } \\
\text { household income, } \\
\text { health insurance, } \\
\text { mother's work status, \# } \\
\text { of adults in household, } \\
\text { cigarette price, alcohol } \\
\text { price, medical services } \\
\text { price, food price }\end{array}$ & $\begin{array}{l}\text { - First trimester prenatal care increased BW by } \\
505 \text { grams, increased GA by } 2.4 \text { weeks, and } \\
\text { increased birth length by } 2.2 \mathrm{~cm} \\
\text { - OLS results: First trimester prenatal care } \\
\text { increased BW by } 67 \text { grams, had negligible } \\
\text { effects on GA, and increased birth length by } \\
0.34 \mathrm{~cm} \\
\text { - Smoking during pregnancy significantly reduced } \\
\text { BW by } 402 \text { grams; did not have significant } \\
\text { effects on GA or length at birth } \\
\text { - OLS: Smoking reduced BW by } 196 \text { gram (effects } \\
\text { on GA not reported);reported "sizeable } \\
\text { negative" effects on birth length }\end{array}$ \\
\hline 18 & $\begin{array}{l}\text { Rous, J.J., Jewell, R.T., } \\
\text { Brown, R.W. (2004). } \\
\text { The effect of prenatal } \\
\text { care on birthweight: a }\end{array}$ & $\begin{array}{l}\text { Number of } \\
\text { prenatal care } \\
\text { visits }\end{array}$ & $\begin{array}{l}\text { Individual-level } \\
\text { BW }\end{array}$ & $\begin{array}{l}\text { Birth records, } \\
\text { Texas, } 1993\end{array}$ & $\begin{array}{l}\text { 3-equation system that } \\
\text { treated prenatal care as } \\
\text { endogenous and } \\
\text { modeled pregnancy }\end{array}$ & $\begin{array}{l}\text { - Marginal effect of one additional prenatal care } \\
\text { visit (at the mean of } 11.4 \text { visits) was } 14.4 \text { grams; } \\
\text { marginal effects of going from no care to one } \\
\text { visit was } 52.7 \text { grams }\end{array}$ \\
\hline
\end{tabular}




\begin{tabular}{|c|c|c|c|c|c|c|}
\hline \# & Article & $\begin{array}{l}\text { Measure(s) of } \\
\text { Prenatal Care }\end{array}$ & \begin{tabular}{|l} 
Birth \\
Outcome(s)
\end{tabular} & Data Source & Method(s) & Findings \\
\hline & $\begin{array}{l}\text { full-information } \\
\text { maximum likelihood } \\
\text { approach. Health } \\
\text { Economics, 13(3), 251- } \\
264 .\end{array}$ & & & & $\begin{array}{l}\text { resolution to account for } \\
\text { sample selection, jointly } \\
\text { estimated using discrete } \\
\text { factor method (full } \\
\text { information maximum } \\
\text { likelihood - FIML) } \\
\text { Identifiers for prenatal } \\
\text { care: \# of Ob/Gyns per } \\
\text { capita in county }\end{array}$ & $\begin{array}{l}\text { - OLS: marginal effect of one additional visit (at } \\
\text { the mean) was } 28.2 \text { grams; marginal effect of } \\
\text { the first visit was } 52.7 \text { grams } \\
\text { - Smoking a pack a day (compared to no prenatal } \\
\text { smoking) reduced BW by } 285 \text { grams in preferred } \\
\text { (FIML estimation) model; similar results (289 } \\
\text { grams) using OLS }\end{array}$ \\
\hline 19 & $\begin{array}{l}\text { Conway, K.S., Deb, P. } \\
\text { (2005). Is prenatal care } \\
\text { really ineffective? or, is } \\
\text { the 'devil' in the } \\
\text { distribution? Journal of } \\
\text { Health Economics. } \\
\text { 24(3), 489-513. }\end{array}$ & $\begin{array}{l}\text { Weeks of } \\
\text { prenatal care } \\
\text { delay }\end{array}$ & $\begin{array}{l}\text { Individual-level } \\
\text { BW }\end{array}$ & $\begin{array}{l}\text { National } \\
\text { Maternal \& } \\
\text { Infant Health } \\
\text { Survey } 1988\end{array}$ & $\begin{array}{l}\text { Finite mixture models } \\
\text { with endogeneity } \\
\text { correction } \\
\text { Identifiers for prenatal } \\
\text { care: State-level } \\
\text { healthcare price index, } \\
\text { population density; } \\
\text { individual-level } \\
\text { cohabitation status, } \\
\text { income, insurance status }\end{array}$ & $\begin{array}{l}\text { - One week of prenatal care delay led to a 30-35 } \\
\text { gram reduction in BW for the latent class of } \\
\text { pregnancies comprising approximately } 86-87 \% \\
\text { of all births, denoted 'normal' pregnancies } \\
\text { (robust to model specification) } \\
\text { - Effect magnitudes were generally similar for } \\
\text { white and black mothers }\end{array}$ \\
\hline 20 & $\begin{array}{l}\text { Evans, W.N., Lien, D. S. } \\
\text { (2005). The benefits of } \\
\text { prenatal care: evidence } \\
\text { from the PAT bus } \\
\text { strike. Journal of } \\
\text { Econometrics, 125(1- } \\
\text { 2), 207-239. }\end{array}$ & $\begin{array}{l}\text { Number of } \\
\text { prenatal care } \\
\text { visits }\end{array}$ & $\begin{array}{l}\text { Individual-level } \\
\text { BW and GA }\end{array}$ & $\begin{array}{l}\text { Birth records, } \\
\text { Allegheny } \\
\text { County, PA, } \\
\text { 1990-1994 }\end{array}$ & $\begin{array}{l}\text { IV } \\
\text { Identifier for prenatal } \\
\text { care: Whether affected } \\
\text { by Port Authority Transit } \\
\text { bus strike in Allegheny } \\
\text { county, based on } \\
\text { geography and timing }\end{array}$ & $\begin{array}{l}\text { - Did not find significant effects of visits on } \\
\text { birthweight or gestational age } \\
\text { - Bus strike significantly reduced the number of } \\
\text { prenatal care visits; magnitude varied across } \\
\text { subsamples } \\
\text { - Similar results in OLS estimations } \\
\text { - Suggestive (but inconclusive) evidence of a } 57 \\
\text { gram decrease in BW for those early in } \\
\text { pregnancy, through decreased number of } \\
\text { prenatal visits }\end{array}$ \\
\hline
\end{tabular}




\begin{tabular}{|c|c|c|c|c|c|c|}
\hline$\#$ & Article & $\begin{array}{l}\text { Measure(s) of } \\
\text { Prenatal Care }\end{array}$ & $\begin{array}{l}\text { Birth } \\
\text { Outcome(s) }\end{array}$ & Data Source & Method(s) & Findings \\
\hline 21 & $\begin{array}{l}\text { Abrevaya, J., Dahl, C.M. } \\
\text { (2008). The effects of } \\
\text { birth inputs on } \\
\text { birthweight. Journal of } \\
\text { Business and Economic } \\
\text { Statistics, 26(4), 379- } \\
\text { 397. }\end{array}$ & $\begin{array}{l}\text { Dummies for } \\
\text { no, care, } \\
\text { second } \\
\text { trimester } \\
\text { initiation, and } \\
\text { third trimester } \\
\text { initiation } \\
\text { (compared to } \\
\text { first trimester } \\
\text { initiation) }\end{array}$ & $\begin{array}{l}\text { Individual-level } \\
\text { BW (quantiles) } \\
\text { at } 10 \text { th, } 25 \text { th, } \\
50 \text { th, } 75 \text { th, and } \\
90^{\text {th }} \text { percentiles }\end{array}$ & $\begin{array}{l}\text { Birth records, } \\
\text { Washington } \\
\text { State (1992- } \\
\text { 2002) \& } \\
\text { Arizona } \\
\text { (1993-2002), } \\
\text { with links } \\
\text { between } \\
\text { mothers' first } \\
\text { \& second } \\
\text { births }\end{array}$ & $\begin{array}{l}\text { Quantile regression with } \\
\text { correlated mother } \\
\text { random effects applied } \\
\text { to panel data (preferred } \\
\text { specification) }\end{array}$ & $\begin{array}{l}\text { - Washington State (estimates similar in panel } \\
\text { and cross-sectional models): No prenatal care } \\
\text { reduced BW by } 323 \text { grams at the } 10^{\text {th }} \\
\text { percentiles of BW, no significant effects at the } \\
25^{\text {th }} \text { to } 90^{\text {th }} \text { percentiles, and increased BW by } \\
271 \text { grams at } 90^{\text {th }} \text { percentile; third trimester } \\
\text { care (versus first trimester care) had positive } \\
\text { effects o } 72 \text { grams at } 25^{\text {th }} \text { percentiles and no } \\
\text { effects at higher percentile } \\
\text { - Washington State: OLS estimates of average } \\
\text { effects for } 2^{\text {nd }} \text { or third trimester care versus first } \\
\text { trimester care were positive (counter-intuitive } \\
\text { result) } \\
\text { - Arizona results similar } \\
\text { - Smoking (Washington State only): Negative } \\
\text { effects of any smoking during pregnancy, } \\
\text { ranging from } 25 \text { grams for lowest quantile to } 57 \\
\text { for highest quantile of BW in panel models. } \\
\text { Average effect was } 57 \text { grams, with strongest } \\
\text { effect ( } 81 \text { grams) at median BW, in panel } \\
\text { regressions } \\
\text { - Cross-sectional effects of smoking (Washington } \\
\text { State) were } 150-200 \text { grams }\end{array}$ \\
\hline 22 & $\begin{array}{l}\text { Mukhopadhyay, S., } \\
\text { Wendel, J., Lee, W., } \\
\text { Yang, W. (2008). } \\
\text { Analyzing the impact of } \\
\text { prenatal care on infant } \\
\text { health: do we have } \\
\text { useful input and output } \\
\text { measures? Economics } \\
\text { Bulletin, 9(22), 1-14. }\end{array}$ & $\begin{array}{l}\text { Numbers of } \\
\text { provider- } \\
\text { reported and } \\
\text { maternal- } \\
\text { reported } \\
\text { prenatal care } \\
\text { visits }\end{array}$ & $\begin{array}{l}\text { Individual-level } \\
\text { BW, LBW, } \\
\text { marginal cost of } \\
\text { providing infant } \\
\text { hospital care }\end{array}$ & $\begin{array}{l}\text { Linked data } \\
\text { from one U.S. } \\
\text { hospital, its } \\
\text { subsidized } \\
\text { prenatal care } \\
\text { clinic, and } \\
\text { birth records }\end{array}$ & OLS & $\begin{array}{l}\text { - Built upon working paper version of Reichman } \\
\text { et al. (2009) } \\
\text { - Each additional self-reported prenatal care visit } \\
\text { reduced marginal cost of care by } .6 \% \text { and LBW } \\
\text { by } .3 \text { ppts; no effects of provider-reported visits } \\
\text { on either outcome }\end{array}$ \\
\hline
\end{tabular}




\begin{tabular}{|c|c|c|c|c|c|c|}
\hline \# & Article & $\begin{array}{l}\text { Measure(s) of } \\
\text { Prenatal Care }\end{array}$ & $\begin{array}{l}\text { Birth } \\
\text { Outcome(s) }\end{array}$ & Data Source & Method(s) & Findings \\
\hline 23 & $\begin{array}{l}\text { Mukhopadhyay, S., } \\
\text { Wendel, J. (2008). Are } \\
\text { prenatal care resources } \\
\text { distributed efficiently } \\
\text { across high-risk and } \\
\text { low-risk } \\
\text { mothers? International } \\
\text { Journal of Health Care } \\
\text { Finance and } \\
\text { Economics, 8(3), 163- } \\
179 .\end{array}$ & $\begin{array}{l}\text { Numbers of } \\
\text { provider- } \\
\text { reported } \\
\text { prenatal care } \\
\text { visits and } \\
\text { months of care }\end{array}$ & $\begin{array}{l}\text { Marginal cost for } \\
\text { the infant } \\
\text { hospital delivery } \\
\text { stay }\end{array}$ & $\begin{array}{l}\text { Linked data } \\
\text { from one U.S. } \\
\text { hospital and } \\
\text { its subsidized } \\
\text { prenatal care } \\
\text { clinic }\end{array}$ & $\begin{array}{l}\text { IV } \\
\text { Identifiers for prenatal } \\
\text { care: Individual-level } \\
\text { health insurance status } \\
\text { and maternal age }\end{array}$ & $\begin{array}{l}\text { - OLS results: } 1 \% \text { increase in months of prenatal } \\
\text { care significantly reduced newborn hospital } \\
\text { costs by } .013 \% \text {, and a } 1 \% \text { increase in number of } \\
\text { prenatal visits reduced newborn hospital costs } \\
\text { by } .03 \% \\
\text { - OLS results: Prenatal care had significant effects } \\
\text { on hospital costs only for mothers at high risk } \\
\text { due to poor obstetrical histories or other pre- } \\
\text { pregnancy health conditions } \\
\text { - IV results: No effects of prenatal care on } \\
\text { hospital costs, once controlling for positive } \\
\text { selection into prenatal care }\end{array}$ \\
\hline 24 & $\begin{array}{l}\text { Reichman, N.E., } \\
\text { Corman, H., Noonan, } \\
\text { K., Dave, D. (2009). } \\
\text { Infant health } \\
\text { production functions: } \\
\text { what a difference the } \\
\text { data make. Health } \\
\text { Economics, 18(7), 761- } \\
782 .\end{array}$ & $\begin{array}{l}\text { Medical record } \\
\text { and self- } \\
\text { reported first } \\
\text { trimester } \\
\text { prenatal care }\end{array}$ & $\begin{array}{l}\text { Individual-level } \\
\text { BW, LBW, } \\
\text { abnormal infant } \\
\text { health } \\
\text { conditions }\end{array}$ & $\begin{array}{l}\text { Fragile } \\
\text { Families and } \\
\text { Child } \\
\text { Wellbeing } \\
\text { survey linked } \\
\text { to medical } \\
\text { records, 1998- } \\
2000\end{array}$ & OLS & $\begin{array}{l}\text { - First trimester prenatal care increased BW by } \\
\text { about } 50 \text { grams, reduced LBW by } 2 \text { ppts, and } \\
\text { reduced abnormal infant health conditions by } 3 \\
\text { ppts using self-reported measure of first } \\
\text { trimester care; no effects of first trimester care } \\
\text { on any birth outcome using prenatal } \\
\text { information from medical records } \\
\text { - Smoking reduced BW by } 213-230 \text { grams, } \\
\text { increased LBW by } 5 \text { to } 7 \text { ppts, and had no effect } \\
\text { on abnormal conditions using self-reported } \\
\text { smoking; smoking reduced BW by } 174 \text { to } 186 \\
\text { grams, increased LBW by } 5 \text { to } 7 \text { ppts, and had } \\
\text { no effect on abnormal conditions using medical } \\
\text { records in combination with self reports }\end{array}$ \\
\hline 25 & $\begin{array}{l}\text { Sonchak, L. (2015). } \\
\text { Medicaid } \\
\text { reimbursement, } \\
\text { prenatal care and } \\
\text { infant health. Journal of } \\
\text { Health Economics, 44, } \\
\text { 10-24. }\end{array}$ & $\begin{array}{l}\text { Prenatal visits, } \\
\text { first trimester } \\
\text { care, no } \\
\text { prenatal care, } \\
\text { Kessner index }\end{array}$ & $\begin{array}{l}\text { Individual-level } \\
\text { BW, LBW, GA, } \\
\text { preterm }\end{array}$ & $\begin{array}{l}\text { Birth records, } \\
\text { U.S., 2001- } \\
2010\end{array}$ & $\begin{array}{l}\text { IV } \\
\text { Identifier for prenatal } \\
\text { care visits: State } \\
\text { Medicaid } \\
\text { reimbursement rate for } \\
\text { obstetric care }\end{array}$ & $\begin{array}{l}\text { - Additional prenatal visits increased BW for } \\
\text { unmarried white women with < high school } \\
\text { education but not similar black mothers; for the } \\
\text { former, one visit increased BW by } 23 \text { grams but } \\
\text { no effects on LBW, GA, or preterm birth } \\
\text { - OLS: Estimates similar to IV estimates for } \\
\text { whites, but indicate a significant effect of } \\
\text { prenatal care visits on birthweight of } 23 \text { grams } \\
\text { for blacks }\end{array}$ \\
\hline
\end{tabular}




\begin{tabular}{|l|l|l|l|l|l|l|}
\hline \multicolumn{2}{|c|}{ Table 1: Studies of effects of prenatal care on birth outcomes from the economics literature } \\
\hline$\#$ & Article & $\begin{array}{l}\text { Measure(s) of } \\
\text { Prenatal Care }\end{array}$ & $\begin{array}{l}\text { Birth } \\
\text { Outcome(s) }\end{array}$ & Data Source & Method(s) & Findings \\
\hline & & & & & & $\begin{array}{l}\text { 10\% increase in fees increased prenatal visits by } \\
.11 \text { for blacks, .07 for whites, and smaller } \\
\text { amounts for more educated mothers; no } \\
\text { significant effects of fees on first trimester } \\
\text { prenatal care, but some effect on Kessner index } \\
\text { and no prenatal care measures among select } \\
\text { groups of mothers }\end{array}$ \\
\hline
\end{tabular}

Notes: 2 SLS = Two-stage Least Squares; BW = Birthweight (grams); DD = Difference in differences; GA = Gestational Age (weeks); IV = Instrumental Variables; LBW = Low Birthweight (<2500 grams); OLS = Ordinary Least Squares; Preterm birth $=<37$ completed weeks GA; ppt $=$ Percentage point; VLBW = Very Low Birthweight ( $<$ 1500 grams); WIC = The Special Supplemental Nutrition Program for Women, Infants, and Children. Findings include estimates for prenatal care, followed by estimates for prenatal smoking (in italics, and for comparative purposes) when available. 